\author{
U.S. Department of the Interior \\ U.S. Geological Survey
}

\title{
Arsenic in Ground Water of the Willamette Basin, Oregon
}

Water-Resources Investigations Report 98-4205

Prepared in cooperation with

OREGON WATER RESOURCES DEPARTMENT 


\section{U.S. Department of the Interior \\ U.S. Geological Survey}

\section{Arsenic in Ground Water of the Willamette Basin, Oregon}

BY STEPHEN R. HINKLE AND DANIAL J. POLETTE

Water-Resources Investigations Report 98-4205

Prepared in cooperation with

OREGON WATER RESOURCES DEPARTMENT

Portland, Oregon: 1999 


\title{
U.S. DEPARTMENT OF THE INTERIOR \\ BRUCE BABBITT, Secretary
}

\author{
U.S. GEOLOGICAL SURVEY
}

Charles G. Groat, Director

The use of firm, trade, and brand names in this report is for identification purposes only and does not constitute endorsement by the U.S. Government.

For additional information write to:

District Chief

U.S. Geological Survey

10615 South East Cherry Blossom Drive

Portland, Oregon 97216

E-mail: info-or@usgs.gov
Copies of this report can be purchased from:
U.S. Geological Survey
Branch of Information Services
Box 25286
Denver, CO 80225-0286
E-mail: infoservices@usgs.gov

Information regarding the Willamette Ground-Water Project is available at:

<http://wwworegon.wr.usgs.gov/projs_dir/willgw/willpage.html>

Information regarding Oregon District activities is available at:

<http://oregon.usgs.gov/> 


\section{CONTENTS}

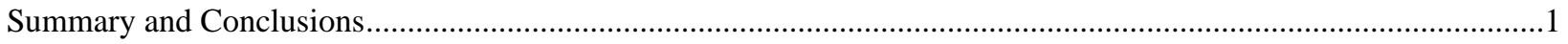

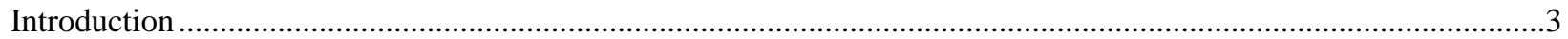

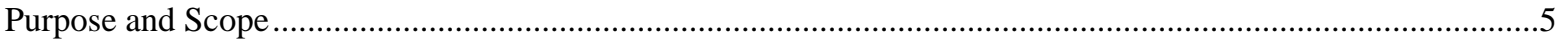

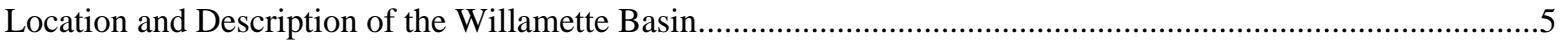

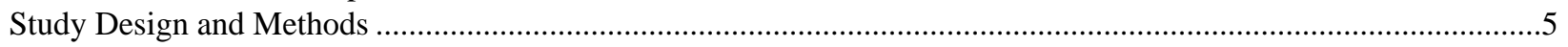

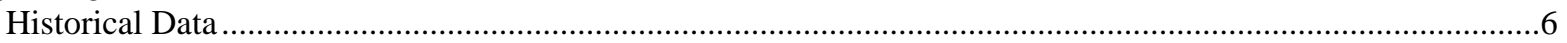

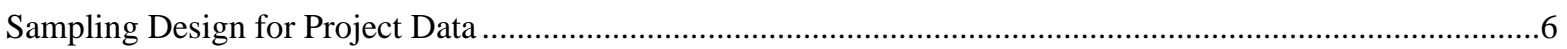

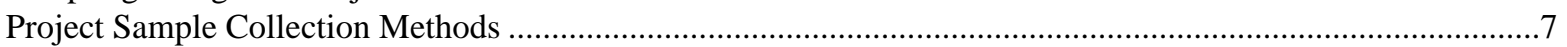

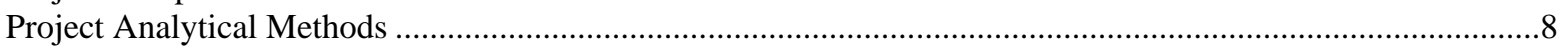

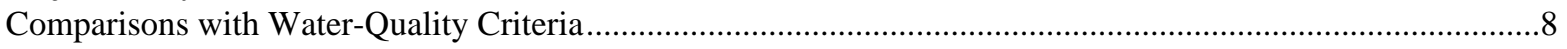

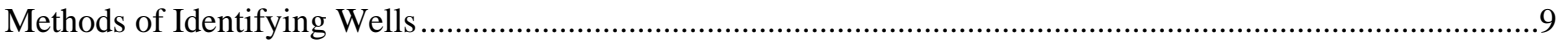

Data Quality: Sampling and Analytical Variability Versus Environmental Variability.......................................10

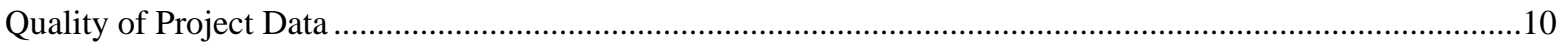

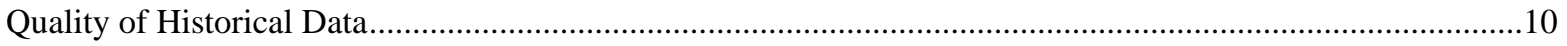

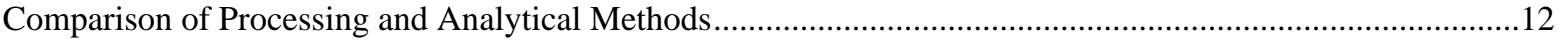

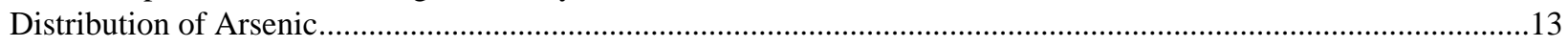

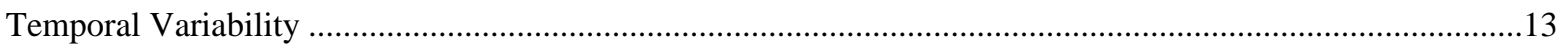

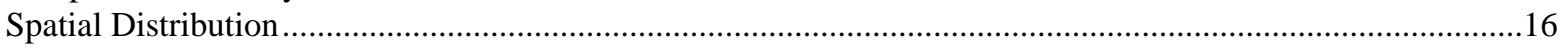

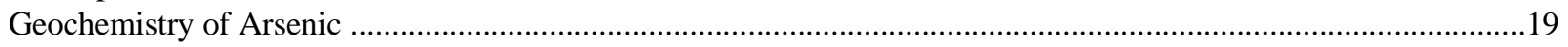

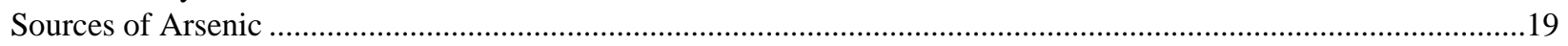

Review of Geochemical Processes Controlling Arsenic Mobility .......................................................................20

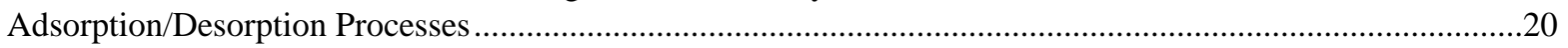

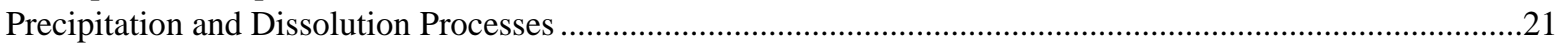

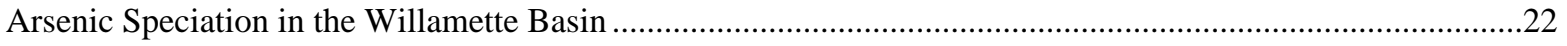

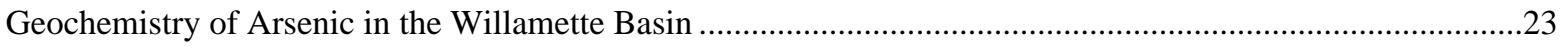

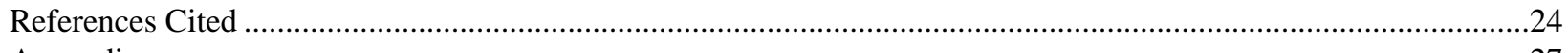

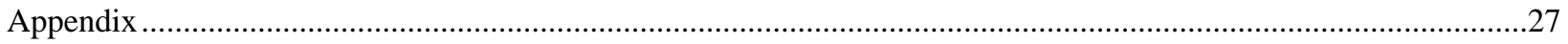

\section{PLATE}

1. Map showing distribution of arsenic concentrations in ground water, and selected geologic units of the Willamette Basin, Oregon......

\section{FIGURES}

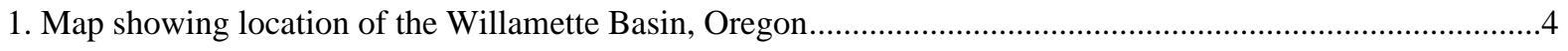

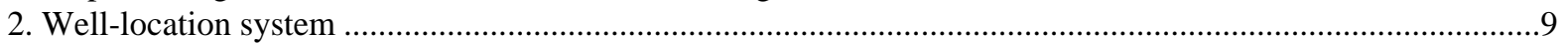

3-6. Graphs showing:

3. Comparison of arsenic concentrations determined by various processing and analytical methods .............13

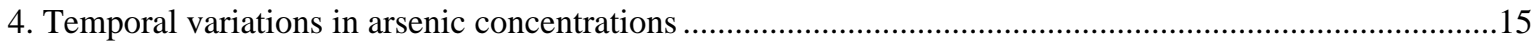

5. Arsenic concentrations for sites sampled in the Willamette Basin, Oregon ......................................17

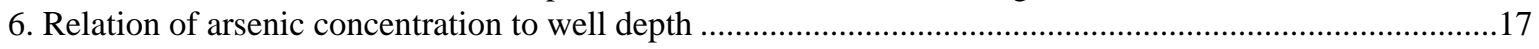

\section{TABLES}

1. Comparison of historical arsenic concentrations with arsenic concentrations measured during this project

2. Comparison of arsenic concentrations for various processing and analytical methods................................12

3. Temporal variations in arsenic concentrations and specific conductance .............................................14

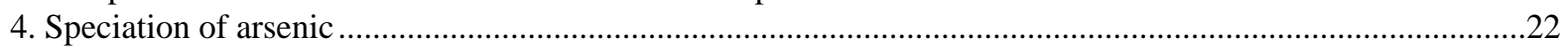




\section{Acknowledgments}

Publication of this report was facilitated by many people. The logistical assistance and technical guidance of the following individuals and organizations were particularly helpful: The Oregon Water Resources Department provided cooperative funding for this work. Rick Partipilo (Linn County Department of Health Services, Environmental Health Program) provided access to county water-quality data. Mark Burkhardt and John Garbarino (U.S. Geological Survey National Water-Quality Laboratory Methods Research and Development Program) expanded on the effort described in this report by performing arsenic-speciation analyses. This report reflects the efforts of a team of technical reviewers, illustrators, and editors. Team members included Terrence Conlon, Doug Lee, Kathy McCarthy, William McFarland, David Morgan, Dennis Nelson (Oregon Health Division Drinking Water Program), Jackie Olson, Donita Parker, Frank Rinella, and John Williams. Finally, this work could not have been done without the assistance of hundreds of well owners who allowed access to wells for sample collection. 


\title{
Arsenic in Ground Water of the Willamette Basin, Oregon
}

\author{
By Stephen R. Hinkle and Danial J. Polette
}

\section{SUMMARY AND CONCLUSIONS}

Arsenic concentrations exceeding the U.S. Environmental Protection Agency (USEPA) current Maximum Contaminant Level (MCL) of $50 \mu \mathrm{g} / \mathrm{L}$ (micrograms per liter) are widespread in ground water in the Willamette Basin. The Oregon Water Resources Department and the U.S. Geological Survey began a cooperative study in the Willamette Basin in 1996. One goal of this study is to characterize the regional distribution of naturally occurring poor-quality ground water, such as ground water with high concentrations of arsenic. Characterization of the regional distribution of arsenic concentrations in the Willamette Basin will be useful to public health officials, water-resource managers, the medical community, and those using ground water for drinking and cooking.

The spatial distribution of arsenic concentrations in ground water of the Willamette Basin was assessed by combining historical data from 597 sites with data from 131 sites collected for this study. A total of 728 spatially distinct samples thus were available. Additional data also were collected to evaluate temporal variability of arsenic concentrations on a seasonal timescale. Samples were collected quarterly from 17 sites for 1 year for this purpose. Temporal variability was addressed for two reasons: First, characterization of temporal variability allowed evaluation of the acceptability of combining arsenic-concentration data collected during different seasons for determining the spatial distribution of arsenic concentrations. Second, knowledge of temporal variability will benefit well owners and water managers who require guidance on timing for sampling.
During the course of quarterly sampling, arsenic concentrations in water from many wells remained essentially constant, but variations of up to almost a factor of three were observed in other wells. No obvious correlation with season was apparent. Analytical accuracy, as determined from 11 standard reference samples submitted during the course of project work, generally was within \pm 10 percent, and always \pm 20 percent. Thus, analytical variability can only explain some of the observed temporal variability. One possible explanation for observed temporal variability in arsenic concentrations is that differences in the amount of pumpage prior to sampling may lead to variations in the amounts of water pumped from different sources (different aquifers or parts of aquifers), and thus, differences in water chemistry.

For a regional assessment of arsenic concentrations in ground water, where arsenic concentrations may vary in space by several orders of magnitude, the relatively smaller temporal variations such as those observed in the quarterly samples are not a significant limitation, and the aggregation of data collected at different times is justified. However, this conclusion may not necessarily apply to all investigations of arsenic concentrations in ground water. For some purposes, site-specific characterization may require characterization of temporal variability. Such characterization may require evaluation over a range of well uses and seasons.

Concentrations of arsenic in the 728 spatially distributed samples ranged from less than 1 to $2,000 \mu \mathrm{g} / \mathrm{L}$. Concentrations in 58 (8.0 percent) of the samples exceeded the USEPA current MCL. 
Regionally, the distribution of arsenic concentrations in ground water of the Willamette Basin appears to be primarily related to aquifer geology. High arsenic concentrations (concentrations exceeding the USEPA current MCL) are widespread in bedrock areas in south-central and eastern Lane County, and Linn County. High concentrations of arsenic also are present in some ground water in the Tualatin Basin (a subbasin in the northwestern part of the Willamette Basin). High arsenic concentrations in Lane and Linn Counties appear to be associated with two regionally extensive associations of rocks, (1) the Fisher and Eugene Formations and correlative rocks, and (2) the undifferentiated tuffaceous sedimentary rocks, tuffs, and basalt. (These rock associations are defined by Walker and MacLeod, 1991. The undifferentiated tuffaceous sedimentary rocks, tuffs, and basalt are approximately equivalent to the Little Butte Volcanic Series of Peck and others, 1964.) At land surface, these two rock associations cover 24 percent of the Willamette Basin. These associations of rocks include extensive volumes of silicic (rhyolitic) volcanic rocks, which are commonly associated with high concentrations of arsenic. High concentrations in the Tualatin Basin are associated with alluvial deposits. At a regional scale, well depth does not appear to be a useful predictor of arsenic concentration in the Willamette Basin. However, depth may be an important parameter on a local scale, particularly where wells of different depth tap aquifers in different geologic units.

Ground waters in bedrock areas in south-central and eastern Lane County, bedrock areas in Linn County, and alluvial areas in the Tualatin Basin may be more likely to yield water high in arsenic than ground water elsewhere in the basin. However, it cannot be assumed that these areas are the only areas in the basin that contain ground water with high concentrations of arsenic. Little or no data exist for many parts of the basin. Even in areas that have been sampled, geohydrologic heterogeneity makes it difficult to formulate mean- ingful generalizations regarding the likelihood of finding high-arsenic ground water. There is no substitute for actual sampling.

Available information, in combination with an understanding of processes known to promote arsenic mobilization, is sufficient to formulate hypotheses that explain arsenic sources and mobilization in the Willamette Basin. However, available geochemical data and interpretations are sparse. Thus, these hypotheses are preliminary, serving mainly to help direct future geochemical investigation in the Willamette Basin.

Anthropogenic sources of arsenic can be significant in some settings. Arsenical pesticides such as lead arsenate have been used in the basin, and arsenic can be released into the environment from industrial sources. However, regional patterns of arsenic occurrence in Willamette Basin ground water are not consistent with either industrial or agricultural sources of arsenic.

Naturally occurring arsenic commonly is found in a variety of solid phases. Arsenic can be a component of volcanic glass in volcanic rocks of rhyolitic to intermediate composition, adsorbed to and coprecipitated with metal oxides (especially iron oxides), adsorbed to clay-mineral surfaces, and associated with sulfide minerals and organic carbon. Examination of these potential arsenic sources for arsenic availability in the Willamette Basin apparently has never been done.

Two categories of processes largely control arsenic mobility in aquifers: (1) adsorption and desorption reactions and (2) solid-phase precipitation and dissolution reactions. Arsenic adsorption and desorption reactions are influenced by changes in $\mathrm{pH}$, occurrence of redox (reduction/oxidation) reactions, presence of competing anions, and solid-phase structural changes at the atomic level. Solid-phase precipitation and dissolution reactions are controlled by solution chemistry, including $\mathrm{pH}$, redox state, and chemical composition. 
Several species of arsenic occur in nature, but arsenate (arsenic V) and arsenite (arsenic III) are the two forms commonly found in ground water. For this study, samples from five domestic wells were analyzed for arsenic species. Two additional analyses for arsenic species in ground water from the Willamette Basin were available in the literature. Arsenite was the predominant species of arsenic in six of these seven samples. The

predominance of arsenite has both geochemical and toxicological implications. From a geochemical standpoint, mobility of arsenite differs from that of arsenate. From a public-health perspective, arsenite is more toxic than arsenate, and arsenite also is more difficult to remove from drinking-water supplies than is arsenate. Seven samples do not characterize regional arsenic speciation patterns. However, if the predominance of arsenite in Willamette Basin samples is substantiated by additional speciation work, public health officials and water managers may need to evaluate the scope of the arsenic problem with regard not only to arsenic concentrations, but also to arsenic speciation.

Existing data, including the speciation data, and published interpretations were used to establish preliminary hypotheses for the evolution of high-arsenic ground water in the Willamette Basin. For ground water in bedrock areas of Lane and Linn Counties, existing information suggests that at least some of the following controlling factors likely are important in adsorption and desorption reactions that often control arsenic mobility: (1) high $\mathrm{pH}$, (2) presence of competing anions, and (3) occurrence of reducing conditions. Existing information did not allow for evaluation of the potential importance of adsorption and desorption reactions related to solid-phase structural changes at the atomic level, or solid-phase precipitation and dissolution reactions.

For alluvial ground water of the Tualatin Basin, presence of competing anions and occurrence of reducing conditions may be important controlling factors in arsenic adsorption and desorption reactions. These two fac- tors might be more important than $\mathrm{pH}$ controls over arsenic adsorption and desorption. Reducing conditions and high concentrations of dissolved iron also suggest that dissolution of iron oxides, with subsequent release of adsorbed and (or) coprecipitated arsenic, may play a role in arsenic mobility in the Tualatin Basin.

Although the regional distribution of arsenic concentrations in ground water of the Willamette Basin has been evaluated by this study, an understanding of how ground water in parts of the basin evolved to contain high concentrations of arsenic has not yet been developed. Limited geochemical data have allowed establishment of preliminary hypotheses to explain the evolution of high-arsenic ground water. Developing an understanding of arsenic sources and processes responsible for evolution of high concentrations of arsenic, though, will require additional geochemical investigation. In particular, thermodynamic evaluation of ground water chemistry and study of solid phases present in aquifers would facilitate development of an understanding of adsorption and desorption and precipitation and dissolution reactions controlling arsenic mobility in the Willamette Basin. A key benefit of detailed geochemical study of arsenic in ground water of the Willamette Basin would be increased predictability of areas likely to yield ground water with high arsenic concentrations. Such increased predictability would be likely to have transfer value beyond the Willamette Basin.

\section{INTRODUCTION}

In response to increasing demands on ground-water resources in the Willamette Basin, Oregon (fig. 1), the Oregon Water Resources Department (OWRD) and the U.S. Geological Survey (USGS) began a cooperative study of the basin's ground-water resources in 1996. This study was designed to increase the current understanding of the ground-water resource, and to better characterize the distribution of naturally occurring poor- 


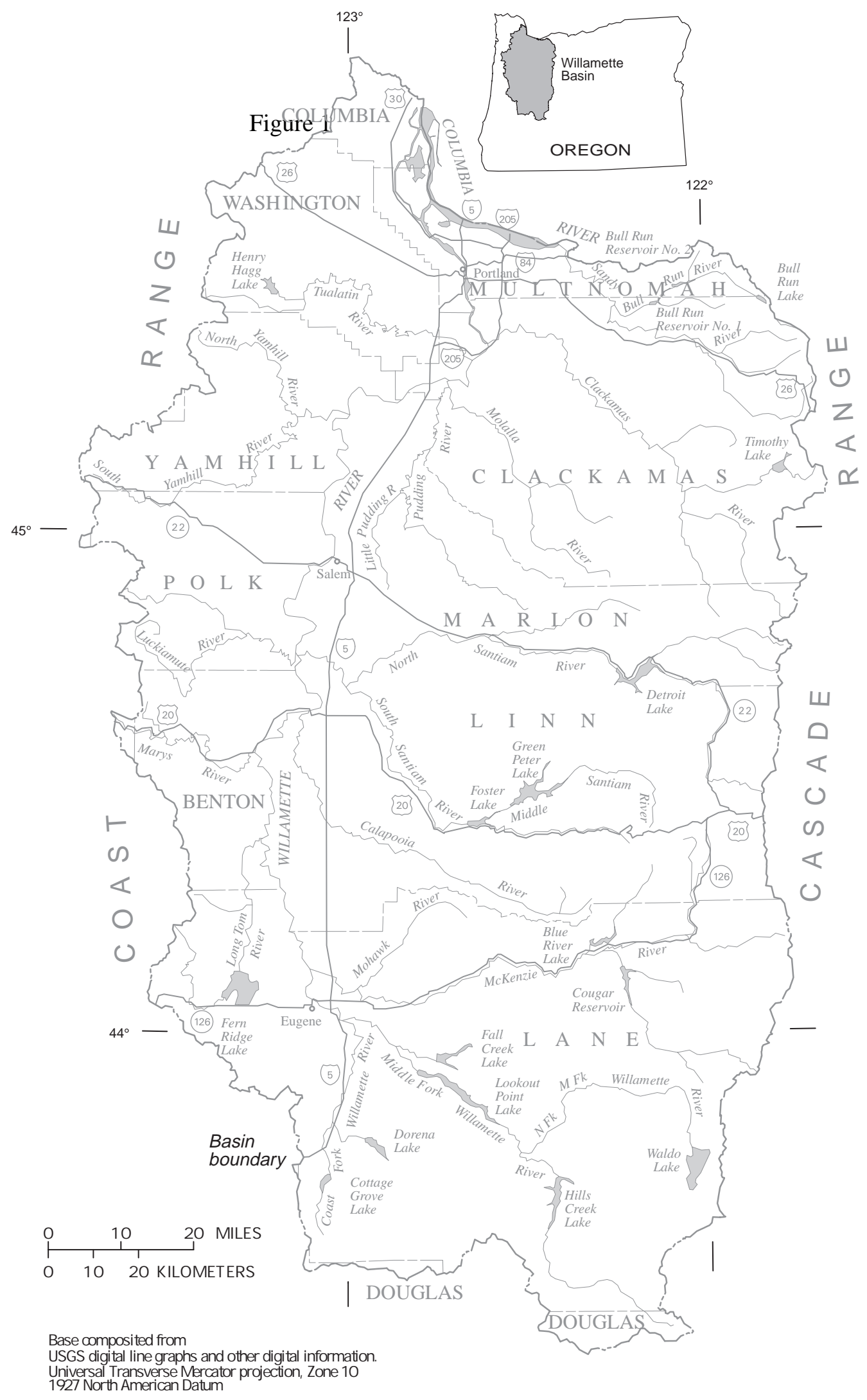

Figure 1. Location of the Willamette Basin, Oregon. 
quality ground water in the basin. Essential components of the study of the physical ground-water resource are the development of a quantitative understanding of regional ground-water availability and flow, and of ground-water/surface-water interactions. Of paramount interest in the characterization of naturally occurring poor-quality ground water in the Willamette Basin is the distribution of arsenic in ground water, the subject of this report.

Arsenic contaminates many regional aquifer systems worldwide (Cantor, 1996; Thornton, 1996), and arsenic commonly is detected in ground water of the Willamette Basin at concentrations exceeding the U.S. Environmental Protection Agency (USEPA) current drinking water Maximum Contaminant Level (MCL) of $50 \mu \mathrm{g} / \mathrm{L}$ (micrograms per liter) (U.S. Environmental Protection Agency, 1996). Arsenic is associated with a number of adverse effects on human health. The USEPA considers arsenic to be a human carcinogen (U.S. Environmental Protection Agency, 1996). Examples of other adverse health effects attributed to consumption of arsenic range from weakness and abdominal pain to neurological and cardiovascular problems. A review of health effects associated with consumption of arsenic is given in a report by World Health Organization (1996).

\section{Purpose and Scope}

The primary purpose of this report is to describe the spatial distribution of arsenic concentrations in ground water of the Willamette Basin. Both historical data and data collected for this study (henceforth, "project data") were used for this purpose. Project data also were used to evaluate temporal variability of arsenic concentrations. It is useful to have an understanding of temporal variability before arsenic-concentration data, collected at different times, is used to evaluate spatial distributions. Evaluation of temporal variability may also benefit well owners and water managers, who may require guidance on timing for sampling.

A secondary purpose of this report is to briefly summarize current knowledge of the geochemistry of arsenic in the Willamette Basin. Relevant geochemical data are few, so this discussion is inherently general, serving mainly to outline future research needs. Possible sources of arsenic are evaluated, and geochemical processes that may control arsenic mobilization are briefly discussed.

\section{Location and Description of the Willamette Basin}

The Willamette Basin is an approximately 12,000-square-mile basin in northwestern Oregon. Primary drainage is by the Willamette River, but for the purposes of the study, the basin is defined to also include the region drained by the Sandy River; both rivers are tributary to the Columbia River. The Willamette Basin was home to 69 percent of the State's population in 1990 (Broad and Collins, 1996).

The crests of two north-south trending mountain ranges, the Coast and the Cascade Ranges, respectively define the western and eastern edges of the Willamette Basin. The Willamette Valley, an elongated, structural and erosional lowland, lies between these mountain ranges. The Coast Range is composed of marine sedimentary rocks and associated volcanic rocks. The Cascade Range is composed of lava flows and pyroclastic and epiclastic rocks. The Willamette Valley is filled with clastic basin-fill sediments of primarily alluvial origin; these alluvial sediments form the most important aquifers in the Willamette Basin. The geologic framework of the basin is described by Gannett and Caldwell (in press), and a regional representation of the surficial geology of the Willamette Basin is given on the geologic map of Oregon compiled by Walker and MacLeod (1991). Usage of geologic names in this report is consistent with that of Walker and MacLeod (1991).

\section{STUDY DESIGN AND METHODS}

The overall approach used to collect, assemble, and analyze data for this report is described in this section. First, a description of the sources of historical data is given, followed by a description of the sampling design for project data. Approaches used to define the quality of both historical and project data are discussed, as are collection and analytical methods used for project data. Finally, benchmarks for comparison of arsenic-concentration data, and methods for identification of well locations, are described. 


\section{Historical Data}

Analysis of historical data (arsenic concentrations and site locations, and in most cases, well depths) from regional ground-water investigations was the starting point for evaluation of distribution of arsenic in the Willamette Basin. Some wells were sampled more than once; in these cases, the first-in-time sample was selected. Four sets of historical data used in this report are described below.

Historical data from the USGS National Water Information System (NWIS) database (Maddy and others, 1990) (271 wells). These data were collected between 1971 and 1997 as parts of various USGS projects. Many of these projects were regional in scope, and thus these data cover large areas in the Willamette Basin. In addition to arsenic concentrations, depth data also were retrieved. Data from both unfiltered and filtered samples were found in NWIS. Some of these NWIS data are discussed in the following reports: Frank and Collins, 1978; Gonthier, 1983; Leonard and Collins, 1983; Hinkle, 1997. Project data, although stored in NWIS, are discussed separately (see section "Sampling Design for Project Data").

Data from four USGS studies (Frank, 1973, 1974, 1976; Helm and Leonard, 1977), not entered into NWIS (89 wells). These data, also from regional-scale projects, encompass large areas in the southern part of the basin. The data were collected between 1964 and 1973 by USGS personnel. Well depths were obtained from tables in the reports. Techniques used to process these samples (in particular, filtering or a lack thereof) are not known.

Data from a USGS study in Lane County, not entered into NWIS (171 wells; 1 nonthermal spring). These data were collected during 196263, and summarized by Goldblatt and others (1963). Many of these wells withdraw water from the arsenic-rich Fisher Formation (Goldblatt and others, 1963). Arsenic concentrations and well depths were compiled from original project notes from USGS files. Samples were collected and analyzed as unfiltered samples (A.S. Van Denburgh, U.S. Geological Survey, oral commun., 1997).

Data from Linn County Department of Health Services, Environmental Health Program (65 wells). More than 100 wells were sampled for arsenic by the Environmental Health Program in
1987. Most of these wells were located near Sweet Home, an area that received little coverage in the three regional data sets listed above. Drillers' logs were on file with the Environmental Health Program for many of these wells. In 1996, USGS personnel were able to locate 65 homes corresponding to addresses from well drillers' logs for sampled wells. Arsenic concentrations from Environmental Health Program files and well depths from well drillers' logs were matched with the home locations to create a data coverage. Samples were probably collected and analyzed as unfiltered samples.

\section{Sampling Design for Project Data}

Project data were collected for several purposes. Ground-water samples were collected to fill gaps in the spatial distribution of the historical data and to illustrate the magnitude of temporal variability in arsenic concentrations. In addition, five ground-water samples were analyzed for arsenic species. Quality-control (QC) data were collected to evaluate the quality of project data, evaluate the quality of historical data (by resampling selected historical sites), and compare results obtained by different processing and analytical methods.

Samples from 125 wells and 6 nonthermal springs were collected during 1996 and 1997 to complement the spatial distribution of historical data. The wells and springs sampled were distributed throughout the lower elevation areas of the Willamette Basin, which are areas of greatest ground-water use. These sites had not previously been sampled for arsenic by the USGS. Some wells were sampled more than once during the course of this project; in these cases, the first-in-time samples were used to define the spatial distribution of arsenic.

To evaluate temporal variability of arsenic concentrations, samples were collected quarterly for 1 year from each of 17 sites. These samples also were collected during 1996 and 1997. A subset (5) of these 17 sites were sampled for arsenic species.

QC samples were used to evaluate the quality of techniques used to collect and analyze project samples. Twelve field equipment blanks, 6 sets of triplicate split samples, and 11 standard reference samples (SRSs) were analyzed over the course of the project. Field equipment blanks allow evaluation of the extent of any sample contamination 
resulting from sample collection, processing, and analysis. Replicate samples allow evaluation of the reproducibility (precision) of analyses. SRSs facilitate evaluation of analytical accuracy. The USGS SRS program, an interlaboratory testing program, is described in a report by Long and Farrar (1995). Preparation, description, and most probable values (MPVs) of constituents of individual SRSs used in this study are described by U.S. Geological Survey (1990) and Long and Farrar (1991, 1993, 1995). An MPV for an analyte is the median of the concentrations determined by the participating laboratories. Analytical results are reported as percentages of SRS-program MPVs.

Additional quality assurance included resampling 11 historical sites. Comparison between historical arsenic concentrations and concentrations determined upon resampling offers a measure of the reliability of historical data.

Comparisons between filtered and unfiltered samples, and between USGS and USEPA analytical methods, also were made. Characterization of differences in arsenic concentrations among unfiltered and filtered samples helps quantify the effect of sample filtering, and increases the transfer value of the data and interpretations presented in this report. Data from comparison of USGS and USEPA analytical methods facilitate comparison of arsenic concentrations determined by USGS methods with USEPA water-quality criteria.

\section{Project Sample Collection Methods}

Project samples from wells and springs used for evaluation of spatial distribution of arsenic were not filtered. Unfiltered samples, in addition to being more economical to collect than samples filtered through $0.45-\mu \mathrm{m}$ (micrometer) filters, also have the advantage of being more representative of the water being consumed by most well owners. Another justification for collection of unfiltered samples is that many of the historical data, with which project data were combined, were from analyses of unfiltered samples. Furthermore, USEPA and World Health Organization (WHO) guidelines for water quality (see section "Comparisons with Water-Quality Criteria“) apply to "finished water." For most project wells, which were primarily domestic wells, "finished water" generally is equivalent to unfiltered water. However, because unfil- tered samples may contain more colloids and (or) more sediment entrained during pumping, unfiltered samples are less representative of water actually moving through an aquifer than are $0.45-\mu \mathrm{m}$-filtered samples. Thus, the use of unfiltered samples in characterization of ground-water quality represents an approximation. Additional, quantitative discussion on this topic is presented in the section, "Comparison of Processing and Analytical Methods."

Of the 125 project wells used for evaluation of spatial distribution of arsenic, 116 were actively used domestic wells. The remaining 9 wells included 3 public-water-supply wells, 3 industrial wells, 2 irrigation wells, and 1 livestock well. Of these nine wells, those that were not actively used were purged a minimum of three casing volumes prior to sampling to remove standing water from the well. Samples from actively used wells were collected following a minimum purge time of 1 minute. Longer purge times, characteristic of most USGS ground-water-quality work, were deemed unnecessary for actively used wells in this project because these wells experienced a degree of regular purging from the frequent use of the wells. A resulting limitation, however, is that samples from these wells may lose arsenic by way of adsorption to iron casing or precipitation as ground water undergoes geochemical changes while residing in a well bore or casing. Thus, arsenic concentrations in samples from these wells may be biased toward low arsenic concentrations relative to water actually moving through the aquifer. The extent of this possible bias has not been quantified, but because these wells were actively used, this potential bias is likely to be small.

Project samples collected from springs were collected from flowing springs. Fine sediment was present along with the water in several of the springs, so spring samples were filtered through $0.45-\mu \mathrm{m}$ nominal-pore-size filters.

Project wells sampled for evaluation of temporal variability in arsenic concentrations were actively used wells, sampled using the same methods as for project wells sampled for evaluation of spatial distribution of arsenic.

Project wells sampled for arsenic speciation also were actively used wells. Samples were collected as unfiltered samples following a minimum well purge time of 1 minute. Samples were col- 
lected without headspace in brown glass vials, wrapped in aluminum foil (to prevent photooxidation), and shipped on ice to the laboratory.

Eleven wells represented in the historical data set were resampled. All were actively used wells and were sampled using the same methods as for project wells sampled for evaluation of spatial distribution of arsenic.

Samples for comparison between filtered and unfiltered samples, and comparison of USGS and USEPA methods, were collected from a subset of the wells sampled for temporal variability. Each 10-liter sample was split in the field by mechanical agitation into four subsamples. One subsample was filtered through a $0.10-\mu \mathrm{m}$ nominal-pore-size 47-mm-diameter filter. One subsample was filtered through a $0.45-\mu \mathrm{m}$ nominal-pore-size $142-\mathrm{mm}$ diameter filter. Two subsamples were collected as unfiltered samples. For each set of the four subsamples, both of the filtered samples and one of the unfiltered samples were analyzed by USGS methods (see section "Project Analytical Methods"). The other unfiltered sample was analyzed by USEPA methods (see section "Project Analytical Methods").

All arsenic samples, except samples collected for analysis of arsenic species, were field-acidified to below pH 2 with nitric acid. Samples for analysis of arsenic species were not acidified.

\section{Project Analytical Methods}

Arsenic analyses were done at the USGS National Water Quality Laboratory (NWQL) in Arvada, Colorado. Most arsenic determinations were done by hydride atomic absorption with a 3-minute sulfuric acid and potassium persulfate digestion (Fishman and Friedman, 1989). This is the standard USGS method, and it is referred to as the "USGS method" in this report. Ten analyses were done by graphite furnace atomic absorption with a 2-hour hydrochloric acid and nitric acid digestion (U.S. Environmental Protection Agency, 1994). This method is referred to as the "USEPA method" in this report. The analytical minimum reporting level (MRL) was $1 \mu \mathrm{g} / \mathrm{L}$ for both methods.

Samples for arsenic speciation were analyzed by the USGS Methods Research and Development Program at the USGS NWQL. Samples were ana- lyzed for two inorganic species, arsenite (arsenic III) and arsenate (arsenic V), and two organic species, monosodium methylarsonate $\left(\mathrm{CH}_{3} \mathrm{AsO}_{3} \mathrm{HNa}\right)$ and sodium dimethylarsinate $\left(\left(\mathrm{CH}_{3}\right)_{2} \mathrm{AsO}_{2} \mathrm{Na}\right)$. Analyses were done by direct injection high-performance liquid chromatography/hydride generation/ inductively coupled plasma-mass spectrometry. Method detection limits (MDLs) were $0.2 \mu \mathrm{g} / \mathrm{L}$ (expressed as mass of arsenic per liter). Samples were analyzed within 48 hours of collection.

\section{Comparisons with Water-Quality Criteria}

To provide benchmarks against which arsenic-concentration data can be compared, arsenic-concentration data are compared with USEPA and WHO drinking-water standards. Concentrations of arsenic are compared to the USEPA current drinking water MCL for arsenic of $50 \mu \mathrm{g} / \mathrm{L}$ (U.S. Environmental Protection Agency, 1996). The USEPA current MCL is the maximum concentration of a contaminant allowed in a public water system. This MCL is under review (U.S. Environmental Protection Agency, 1996). Bagla and Kaiser (1996) report that the USEPA is considering reducing the current MCL by 90 percent. However, until any such reduction in the MCL occurs, the current MCL remains a logical benchmark for comparison. As an alternative benchmark, concentrations of arsenic also are compared to the WHO provisional guideline of $10 \mu \mathrm{g} / \mathrm{L}$ (World Health Organization, 1996).

Water with an arsenic concentration below the USEPA current MCL or WHO provisional guideline is not necessarily free from health risks. For example, arsenic concentrations may be below the USEPA current MCL and WHO provisional guideline, but still be greater than the USEPA drinking-water Risk-Specific-Dose Health Advisory (RSDHA) of $2 \mu \mathrm{g} / \mathrm{L}$ (U.S. Environmental Protection Agency, 1996). (The RSDHA is defined as the concentration of a contaminant in drinking water that is expected to result in a specified increased risk of cancer. The USEPA RSDHA for arsenic is calculated at the 1-in-10,000 cancer risk level. Consumption of water containing a contaminant at the RSDHA 1-in-10,000 risk level is expected to be associated with the following risk: a $70-\mathrm{kg}$ adult drinking $2 \mathrm{~L}$ of such water per day for 70 years faces an increased risk of cancer of 
approximately 1 in 10,000.) Furthermore, effects of arsenic consumption on human health are not uniform among different people, and no single threshold can be defined as the dividing line between "safe" and "unsafe." Comparison of arsenic data to the USEPA current MCL and WHO provisional guideline are done solely for illustrative purposes; no implication of "safety" or lack thereof is implied.

\section{Methods of Identifying Wells}

All wells discussed in this report were assigned well location names corresponding to well locations. Well locations generally were determined when the wells were first visited. Well locations were identified using the Township, Range, and Section method of land subdivision. Two methods are shown on figure 2. Most wells were identified with a system that uses nested groups of the letters A, B, C, and D for section subdivision. Prior to about 1967, wells were identified with an alternative system, using letters A through $\mathrm{R}$ (excluding I and $\mathrm{O}$ ) for section subdivision. To preserve linkage to historical data sources, all wells discussed in this report are referred to by the well location names originally assigned to them. It should be noted, however, that in some cases, the original well location names do not accurately describe the true locations of the wells. To provide accurate locational and identifying information for wells discussed in this report, corrected well locations, and additional identifying information (USGS site identification number and OWRD well log identification number), are listed along with original well locations in the

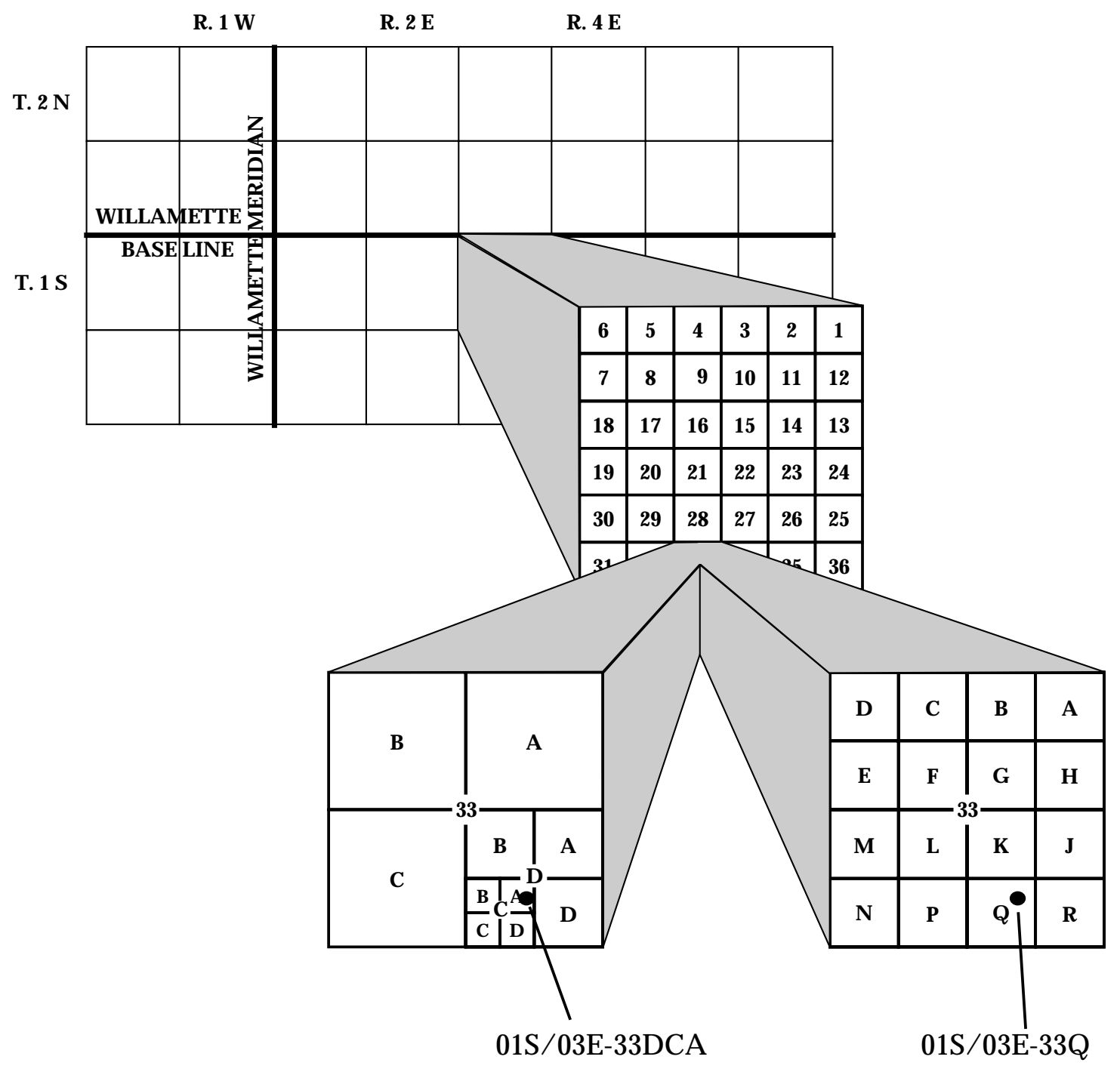

Figure 2. Well-location system. 
Appendix. Note that in the project data report (Orzol and others, in press), wells are listed by corrected well location names.

\section{DATA QUALITY: SAMPLING AND ANALYTICAL VARIABILITY VERSUS ENVIRONMENTAL VARIABILITY}

In this section, project QC data are evaluated to characterize sampling and analytical variability. Sampling and analytical variability must be evaluated before environmental variability can be addressed. Three sets of QC data were collected as part of project data-collection activities. First, sampling and analytical variability of project data are evaluated. Second, the quality of historical data is discussed. Evaluation of historical data is difficult because few historical quality-control data are available. However, resampling of historically sampled sites provides insight into the quality of the historical data. Third, a comparison of sample processing and analytical methods is presented; these data illustrate the magnitude of the differences that can arise from use of various sample processing and analytical methods.

\section{Quality of Project Data}

All 12 project field equipment blanks yielded arsenic concentrations below the MRL of $1 \mu \mathrm{g} / \mathrm{L}$. These results indicate that field and laboratory methods were noncontaminating.

The coefficient of variation (CV) (standard deviation divided by mean, expressed in percent) for each of the six sets of project triplicate split samples ranged from 0.0 to 14 percent. The median $\mathrm{CV}$ was 6.0 percent.

Analytical accuracy of project data was quantified with data from 11 SRSs. Analytical accuracy ranged from 92 to 110 percent for nine of the SRSs, but was 82 and 120 percent for the other two SRSs. In other words, reported concentrations were in error by up to about \pm 20 percent.

Contamination-free sampling and analysis, and reasonable analytical precision and accuracy, indicate that project data were adequate for definition of patterns of regional arsenic occurrence. However, because analytical accuracy was observed to range up to about \pm 20 percent, definitive characterization of temporal variability at individual sites is compromised where temporal variability also is on the order of \pm 20 percent or less.

\section{Quality of Historical Data}

The quality of project data is well characterized, so comparison of project and historical arsenic concentrations yields a measure of the quality of the historical data. Evaluation of the analytical accuracy of historical data is particularly desirable. However, arsenic concentrations determined in original studies and determined again during this study may differ for a variety of reasons unrelated to differences in data quality. Notably, differences between historical arsenic concentrations and arsenic concentrations determined from sampling during this project may reflect changes in the source of water being sampled at different times. Changes in the source of water being sampled can arise for a number of reasons. Ground-water flowpaths in aquifers can change over seasonal or longer time scales. Also, water often flows into wells from more than one permeable zone, and the relative contributions from different zones can change as pumping stresses change. Thus, changes in type of well use (for example, change from domestic use to lawn-watering use) or differences in the history of well use prior to sampling can result in changes in the source of water being withdrawn from wells. Finally, changes in well construction or well characteristics (for example, well cave-in over time) can result in changes in source water for wells. (Note, however, that none of the 11 wells were known to have been deepened between the time of historical sampling and the time of project resampling.) In addition to changes in source water to wells, variability in arsenic concentrations can arise from differences in sample processing prior to analysis, or, especially in the case of unfiltered samples, differences in the amount of colloid- or sediment-bound arsenic. Therefore, an absence of strong correlation between historical and project arsenic concentrations is not necessarily cause for rejection of the historical data. Because differences between historical and project data can arise from a number of factors in addition to differences in data quality, the central purpose for which the resampling data were collected was to determine if the magnitudes of the historical data are adequate 
for definition of patterns of regional arsenic occurrence.

Data from the 11 sites with historical data that were resampled are presented in table 1. Differences between historical and project data are variable. For example, a difference of less than 10 percent was observed for well 19S/03W-31E1, whereas an order-of-magnitude difference was observed for well 22S/03W-17N. However, historical and project arsenic concentrations were in agreement when interpreted relative to exceedances of the USEPA current MCL. Sites at which historical arsenic concentrations exceeded the USEPA current MCL also yielded water exceeding the USEPA current MCL upon sampling during this project, and sites at which historical arsenic concentrations were less than the USEPA current MCL also yielded water below the USEPA current MCL upon sampling during this project. The historical data therefore indicate a similar pattern of spatial variability of arsenic concentrations as the project data.

Closer examination of these data indicates that data from the early 1960 s generally correlate poorly with project data, whereas later data demonstrate reasonably good correlation. This pattern may reflect improvements in analytical techniques since the early 1960 s.

Because two historical samples dating from the mid- to late-1960s (wells 12S/01W-29N1 and 18S/04W-14ACB) had both arsenic and chloride data, these sites were sampled for chloride as well as arsenic during project sampling (table 1). For well $12 \mathrm{~S} / 01 \mathrm{~W}-29 \mathrm{~N} 1$, both the arsenic and chloride concentrations were slightly lower upon project sampling: the arsenic concentration upon project sampling was 86 percent of the historical concentration, and the chloride concentration, 88 percent of the historical concentration. For well 18S/04W$14 \mathrm{ACB}$, both the arsenic and the chloride concentrations were considerably lower upon project sampling: the arsenic concentration upon project sampling was 60 percent of the historical concentration, and the chloride concentration, 33 percent of the historical concentration. Historical chloride concentrations would be expected to be reliable, and would have been negligibly affected by sample processing or the presence of colloids and sediment. Thus, the changes in chloride concentrations suggest that changes in the source of water being pumped by these two wells have occurred over time. If historical chloride concentrations had been similar to project chloride concentrations, then the historical arsenic analyses might be suspect. However, differences in chloride concentrations between historical and project sampling suggest that differences in arsenic concentrations between historical and project sampling were a result, at least in part, of changes in the source of water being pumped by these wells.

Comparison of historical arsenic concentrations and arsenic concentrations determined upon project sampling indicate that historical arsenic concentrations will not necessarily reflect current arsenic concentrations. Use of historical data in process-oriented geochemical studies could be problematic. However, the comparison does

Table 1. Comparison of historical arsenic concentrations with arsenic concentrations measured during this project [Well location as recorded in original data source; arsenic concentrations in micrograms per liter; "--", unknown]

\begin{tabular}{|c|c|c|c|c|c|}
\hline \multirow[b]{2}{*}{ Source for historical data } & \multirow[b]{2}{*}{ Well location } & \multicolumn{2}{|c|}{ Historical data } & \multicolumn{2}{|c|}{ Project resampling } \\
\hline & & Date & $\begin{array}{c}\text { Arsenic } \\
\text { concentration }\end{array}$ & Date & $\begin{array}{c}\text { Arsenic } \\
\text { concentration }\end{array}$ \\
\hline USGS files; Goldblatt and others, 1963 & 18S/04W-22B & $10 / 04 / 62$ & 160 & $08 / 20 / 97$ & 820 \\
\hline USGS files; Goldblatt and others, 1963 & $18 \mathrm{~S} / 04 \mathrm{~W}-10 \mathrm{D}$ & $10 / 17 / 62$ & 120 & 08/20/97 & 520 \\
\hline USGS files; Goldblatt and others, 1963 & $22 \mathrm{~S} / 03 \mathrm{~W}-17 \mathrm{~N}$ & $10 / 25 / 62$ & 32 & 09/05/96 & 3 \\
\hline USGS files; Goldblatt and others, 1963 & 19S/03W-11E2 & $01 / 08 / 63$ & 420 & $11 / 13 / 96$ & 700 \\
\hline USGS files; Goldblatt and others, 1963 & 19S/03W-31E1 & $03 / 29 / 63$ & 120 & $11 / 13 / 96$ & 130 \\
\hline Frank, F.J., 1973 & $18 \mathrm{~S} / 04 \mathrm{~W}-14 \mathrm{ACB}$ & $06 / 12 / 69$ & $500^{\mathrm{a}}$ & 09/06/96 & $300^{\mathrm{b}}$ \\
\hline Helm and Leonard, 1977 & $12 \mathrm{~S} / 01 \mathrm{~W}-29 \mathrm{~N} 1$ & $06 / 24 / 65$ & $70^{\mathrm{c}}$ & $08 / 29 / 96$ & $60^{\mathrm{d}}$ \\
\hline Linn County Dept. of Health Services & $13 \mathrm{~S} / 01 \mathrm{E}-33$ & $--/--/ 87$ & 10 & 09/06/96 & 4 \\
\hline Linn County Dept. of Health Services & 14S/01E-05 & $--/--/ 87$ & 74 & 09/06/96 & 89 \\
\hline Linn County Dept. of Health Services & $13 \mathrm{~S} / 01 \mathrm{E}-33 \mathrm{AC}$ & $04 / 09 / 87$ & 900 & 09/06/96 & 790 \\
\hline Linn County Dept. of Health Services & 13S/01E-35 & $07 / 06 / 87$ & $<5$ & 09/06/96 & 3 \\
\hline
\end{tabular}

${ }^{\mathrm{a}}$ Chloride concentration 43 milligrams per liter.

${ }^{\mathrm{b}}$ Chloride concentration 14 milligrams per liter.

${ }^{\mathrm{c}}$ Chloride concentration 26 milligrams per liter.

${ }^{\mathrm{d}}$ Chloride concentration 23 milligrams per liter. 
suggest that the historical data are adequate for definition of patterns of regional arsenic occurrence.

\section{Comparison of Processing and Analytical Methods}

Hydrologists employ a variety of sample processing and analytical methods in geochemical and water-quality studies. Samples may be collected as unfiltered or as filtered samples. Filtering may be done using any of a variety of pore sizes, but $0.10-\mu \mathrm{m}$ and $0.45-\mu \mathrm{m}$ pore sizes are most commonly used. Analysis of arsenic usually is done using either hydride atomic absorption (commonly used by the USGS) or by graphite furnace atomic absorption (commonly used by the USEPA).

When combining data collected by a number of investigators using a variety of sample processing and analytical methods, questions about the comparability of data arise. Furthermore, comparison of analyses performed using non-USEPA analytical methods against USEPA water-quality criteria raises questions about comparability of analytical techniques. Information on comparability of different sample processing and analytical methods is given in this section. Data from split samples that were (1) filtered through $0.10-\mu \mathrm{m}$ nominal-pore-size filters and analyzed by hydride atomic absorption, (2) filtered through $0.45-\mu \mathrm{m}$ nominal-pore-size filters and analyzed by hydride atomic absorption, (3) analyzed as unfiltered samples using hydride atomic absorption, and (4) analyzed as unfiltered samples using graphite furnace atomic absorption are shown in table 2 and on figure 3 .
Differences in reported arsenic concentrations between unfiltered and filtered samples generally were small. However, one set of samples (from well 21S/03E-08CBD2) demonstrated that concentrations of arsenic in unfiltered samples can be considerably greater (factor of three) than those in filtered samples. Differences between unfiltered and filtered samples may result from differences in the amount of colloid- or sediment-associated arsenic in the samples. Concentrations in both the unfiltered and the filtered samples from this site were greater than the USEPA current MCL, so interpretation was not affected significantly. However, interpretation of data from other sites could conceivably be affected by such differences between unfiltered and filtered samples and investigators will need to bear such potential differences in mind. Overall, however, combining filtered and unfiltered samples appears to be acceptable for definition of patterns of regional arsenic occurrence.

Differences in reported arsenic concentrations between the two analytical methods were small. Arsenic concentrations reported for samples analyzed by the USEPA method were slightly higher than those analyzed by the USGS method. These differences could be a result of differences in analytical methods. The longer digestion associated with the USEPA method could result in differences in reported arsenic concentrations. Different reagents used in sample digestion in the two methods also could result in differences in reported arsenic concentrations. However, the observed differences also could simply represent analytical variability.

Table 2. Comparison of arsenic concentrations for various processing and analytical methods

[USGS, U.S. Geological Survey; USEPA, U.S. Environmental Protection Agency; arsenic concentrations in micrograms per liter; processing and analytical methods described in text]

\begin{tabular}{lcccc}
\hline Well location & $\begin{array}{c}\text { Filtered, } \\
\text { 0.10-micrometer } \\
\text { filter }\end{array}$ & $\begin{array}{c}\text { Filtered, } \\
\text { 0.45-micrometer } \\
\text { filter }\end{array}$ & $\begin{array}{c}\text { Unfiltered (USGS } \\
\text { method) }\end{array}$ & $\begin{array}{c}\text { Unfiltered (USEPA } \\
\text { method) }\end{array}$ \\
\hline 01N/03W-04CCC & 54 & 57 & 53 & 64 \\
01N/03W-07CCD1 & 17 & 17 & 16 & 22 \\
01N/03W-15ADB1 & 47 & 47 & 53 & 60 \\
01S/03W-10BCA1 & 55 & 57 & 59 & 64 \\
02S/02W-11CCD1 & 16 & 16 & 20 & 24 \\
15S/01W-23CCA & 18 & 18 & 18 & 21 \\
17S/01W-24DCA & 70 & 75 & 70 & 46 \\
19S/01W-03ADB & 41 & 43 & 40 & 180 \\
21S/03E-08CBD2 & 62 & 64 & 180 & 1,200 \\
18S/04W-14BBA & 1,100 & 1,100 & 1,100 & \\
\hline
\end{tabular}



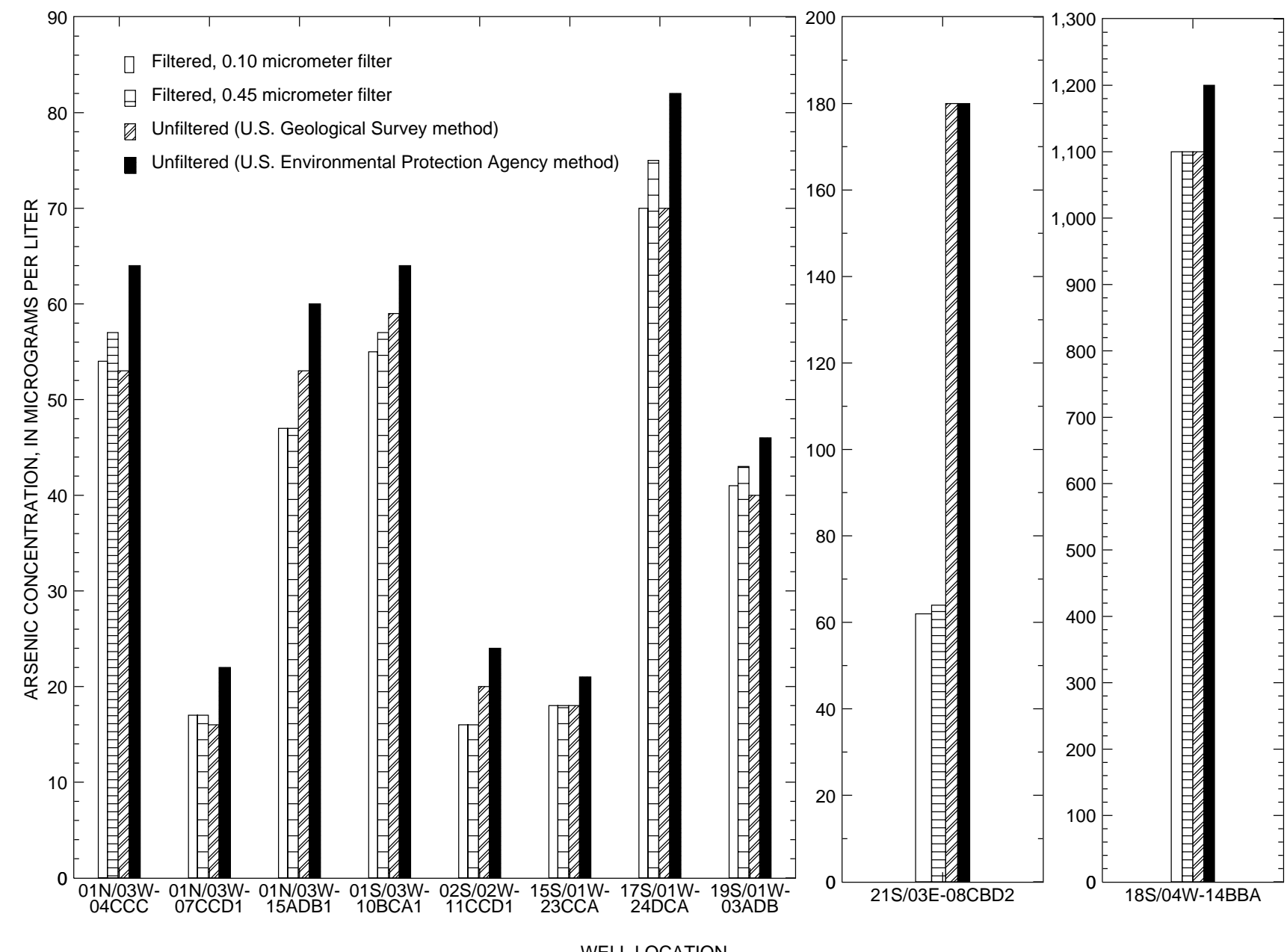

Figure 3. Comparison of arsenic concentrations determined by various processing and analytical methods.

\section{DISTRIBUTION OF ARSENIC}

The distribution of arsenic in ground water of the Willamette Basin is discussed in terms of temporal and spatial variability. First, project data are used to assess temporal variability. It is useful to assess temporal variability before arsenic-concentration data collected at different times is used to evaluate spatial distribution. Also, assessment of temporal variability should benefit well owners and water managers who desire guidance on when to sample for arsenic. Second, historical and project data are used to define spatial variability of arsenic concentrations in ground water in the Willamette Basin.

\section{Temporal Variability}

Project data were used to evaluate temporal variability of arsenic concentrations in ground water during a 1-year period. These data help characterize variability resulting from seasonal and other short- to medium-term factors. Characterization of temporal variability in arsenic concentrations over longer periods of time was not explicitly done, but long-term variability was discussed qualitatively in a previous section of this report, "Quality of Historical Data."

Arsenic concentrations measured quarterly over a period of 1 year at 17 sites are given in table 3 and shown on figure 4 . Field-measured specific conductance, a surrogate for dissolved solids, also is given in table 3 . Arsenic concentrations did exhibit temporal variability. Although arsenic concentrations in water from many wells remained essentially constant over the course of sampling, concentrations at some sites varied by up to almost \pm 50 percent from mean concentrations, and arsenic concentrations in samples from well 19S/01W- 
Table 3. Temporal variations in arsenic concentrations and specific conductance

["As", arsenic concentration in $\mu \mathrm{g} / \mathrm{L}$ (micrograms per liter); "SC", field-measured specific conductance in $\mu \mathrm{S} / \mathrm{cm}$ (microsiemens per centimeter) at 25 degrees Celsius; “--", not measured]

\begin{tabular}{|c|c|c|c|c|c|c|c|c|c|c|c|c|c|c|c|}
\hline Well location & Date & As & SC & Date & As & SC & Date & As & SC & Date & As & SC & Date & As & SC \\
\hline $01 \mathrm{~N} / 03 \mathrm{~W}-04 \mathrm{CCC}$ & $11 / 21 / 96$ & 53 & 587 & $02 / 20 / 97$ & 52 & 585 & $05 / 15 / 97$ & 82 & 496 & $08 / 19 / 97$ & 97 & 522 & $12 / 05 / 97$ & 72 & 616 \\
\hline $01 \mathrm{~N} / 03 \mathrm{Y}$ & 96 & 16 & 345 & & 17 & 357 & 97 & 19 & 345 & /97 & 26 & 314 & $/ 97$ & 18 & 345 \\
\hline $01 \mathrm{~N} / 03 \mathrm{~W}-1$ & 96 & 53 & 1,220 & & 47 & 1,300 & 197 & 64 & 1,390 & 9/97 & 63 & 1,500 & 197 & 52 & 1,450 \\
\hline $01 \mathrm{~S} / 02 \mathrm{~W}-$ & 96 & 33 & -- & 97 & 28 & 194 & & 35 & 193 & 197 & 41 & 195 & 197 & 29 & 192 \\
\hline $01 \mathrm{~S} / 0$ & & 12 & -- & & 10 & 274 & & 12 & 272 & & 13 & 275 & & 12 & 274 \\
\hline $01 \mathrm{~S} / 03$ & & 59 & 341 & & 52 & 340 & & 62 & 339 & & 56 & 339 & 197 & 56 & 341 \\
\hline $02 \mathrm{~S} / 02$ & & 20 & 335 & & 16 & 335 & & 18 & 334 & & 19 & 336 & & 18 & 336 \\
\hline $15 \mathrm{~S} / 01$ & & 19 & 268 & & 18 & 263 & & 19 & 261 & $05 /$ & 17 & 262 & /97 & 19 & 262 \\
\hline $15 \mathrm{~S} / 01 \mathrm{~W}-2$ & 08/14/96 & 11 & 164 & $11 / 1$ & 11 & 167 & $02 / 1$ & 10 & 163 & 05/13/97 & 9 & 161 & 08/20/97 & 12 & 164 \\
\hline $17 \mathrm{~S} / 01$ & 09/06/96 & 85 & 194 & & 70 & 198 & $02 /$ & 74 & 195 & $05 /$ & 84 & 191 & 97 & 69 & 193 \\
\hline $18 \mathrm{~S} / 04$ & 09/05/96 & 9 & 319 & & 6 & 293 & & 5 & 253 & $05 / 14 / 97$ & 6 & 250 & /97 & 10 & 320 \\
\hline 18S/04W-14BBA & 09/04/96 & 830 & 1,040 & $11 / 15 / 96$ & 1,100 & 1,070 & $02 / 20 / 97$ & 640 & 797 & $\mathrm{a}$ & - & a & $08 / 20 / 97$ & 1,100 & 1,060 \\
\hline 19S/01W-03ADB & 09/04/96 & 15 & 188 & $11 / 14 / 96$ & 40 & 329 & & 23 & 193 & $05 / 13 / 97$ & 33 & 237 & 08 & 28 & 205 \\
\hline 19S/03 & $11 / 13 / 96$ & 700 & 389 & & 710 & 393 & & 740 & 39 & $/ 97$ & 850 & 391 & & 800 & 390 \\
\hline 19S/03W-31E1 & $11 / 13 / 96$ & 130 & 295 & $02 / 19 / 97$ & 130 & 295 & $05 / 14 / 97$ & 140 & 291 & $08 / 20 / 97$ & 130 & 285 & $12 / 04 / 97$ & 130 & 292 \\
\hline 21S/03E-08CBD2 & 09/05/96 & 140 & 1,590 & $11 / 14 / 96$ & 180 & 1,460 & $02 / 18 / 97$ & 130 & 1,120 & $05 / 13 / 97$ & 100 & 1090 & 09/04/97 & 69 & 1,450 \\
\hline $22 \mathrm{~S} / 03 \mathrm{~W}-17 \mathrm{~N}$ & 09/05/96 & 3 & 298 & $11 / 13 / 96$ & 3 & 292 & $02 / 19 / 97$ & 4 & 276 & $05 / 14 / 97$ & 4 & 295 & 09/04/97 & 4 & 381 \\
\hline
\end{tabular}

\footnotetext{
${ }^{\mathrm{a}}$ Four samples within 37 hours:

05/13/97 at 7 p.m., As, $1100 \mu \mathrm{g} / \mathrm{L} ; \mathrm{SC}, 1090 \mu \mathrm{S} / \mathrm{cm}$ 05/14/97 at 10 a.m., As, $810 \mu \mathrm{g} / \mathrm{L}$; SC, $952 \mu \mathrm{S} / \mathrm{cm}$ 05/14/97 at 8 p.m., As, $880 \mu \mathrm{g} / \mathrm{L} ; \mathrm{SC}, 809 \mu \mathrm{S} / \mathrm{cm}$ 05/15/97 at 8 a.m., As, $600 \mu \mathrm{g} / \mathrm{L}$; SC, $877 \mu \mathrm{S} / \mathrm{cm}$.
}

03ADB varied by a factor of 2.7 between the lowest and highest concentrations. The data as a whole demonstrate no obvious correlation with seasons. Analytical variability may be responsible for some of the observed variability, but can only explain up to about \pm 20 -percent variation among samples. Differences in arsenic concentrations also could be due, in part, to temporally varying amounts of colloid- or sediment-bound arsenic. However, 10 of the 17 wells used for quarterly sampling also were used in the comparison of unfiltered and filtered samples. The resulting data showed little colloidor sediment-bound arsenic present in samples from those wells at that time, except for well $21 \mathrm{~S} /$ 03E-08CBD2. Clearly, other factors are responsible for some of the observed temporal variability in arsenic concentrations.

It is likely that temporal variability in project data reflects variation in contributing sources of water to wells, and in the absence of seasonal patterns in temporal data, variation in contributing sources to wells is probably largely due to shortterm (hour-to-hour or day-to-day) variations in well use prior to sampling. Relatively heavy well use can temporarily deplete water from parts of an aquifer adjacent to the well, and thus the well can yield water of different chemical quality than when sampled after a period of relatively light use. Two pieces of evidence suggest that some of the 17 wells sampled for temporal variability yield water from different sources at different times, although a relation between differences in contributing sources to wells and differences in well use remains only a hypothesis. One piece of evidence for changing water sources to wells lies in the specific conductance data. Specific conductance generally was less variable in samples where arsenic concentrations were less variable (table 3). Furthermore, specific conductance had the greatest relative temporal variability for water from well 19S/

$01 \mathrm{~W}-03 \mathrm{ADB}$; the same site also had the greatest relative temporal variability in arsenic concentrations (table 3). Because large changes in the chemistry of individual bodies of ground water generally take place over a period of years, it is difficult to explain large seasonal changes in specific conductance of well water by processes other than changing water sources to wells. A second piece of evidence suggesting changing water sources to wells is derived from examination of data from well 18S/04W-14BBA. Maximum and minimum arsenic concentrations in samples from this site varied by nearly a factor of two over the course of a year. At this site, some additional temporal sampling was conducted. Four samples were collected over one 37 -hour period. The observed variability during a 


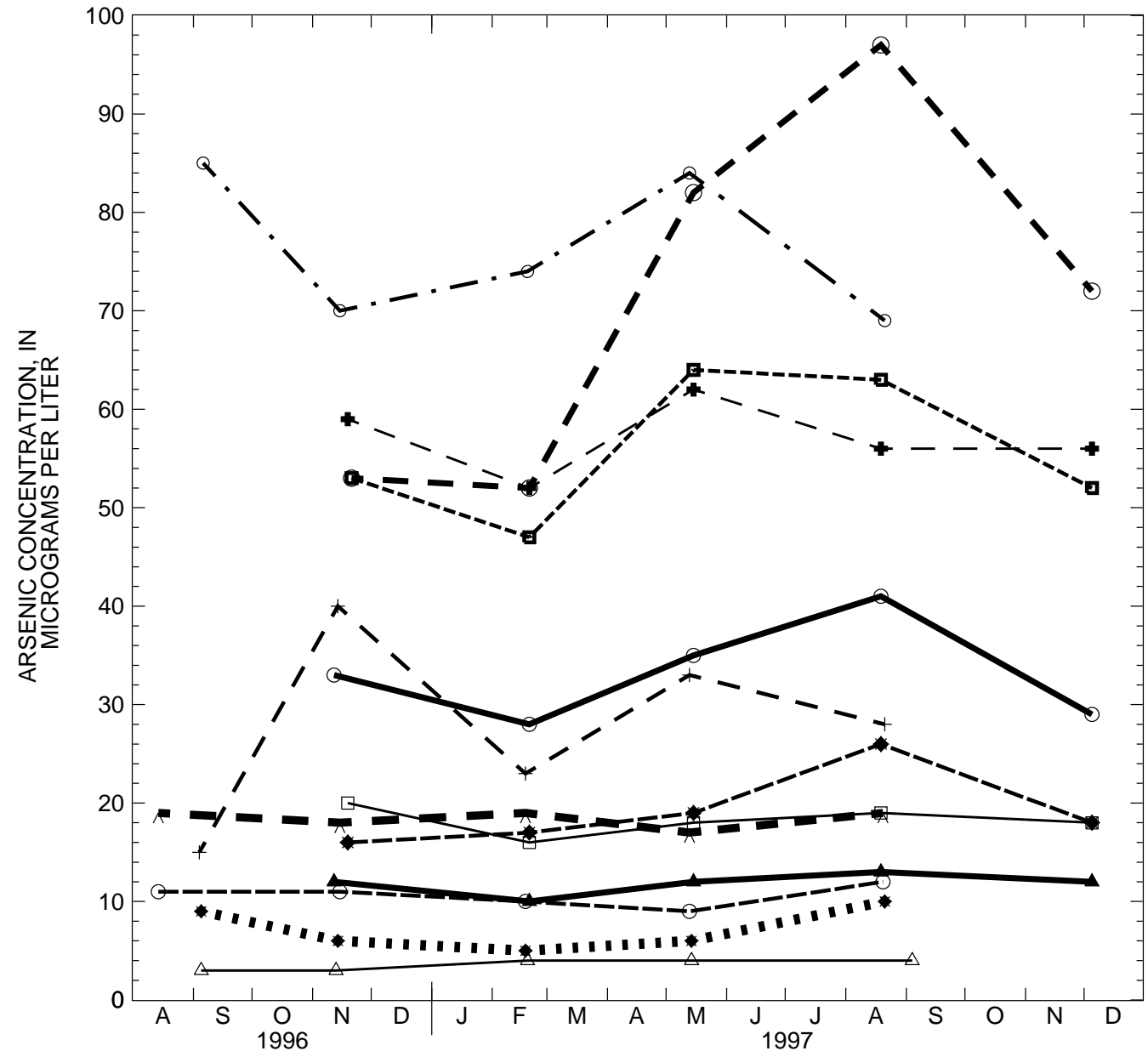

DATE

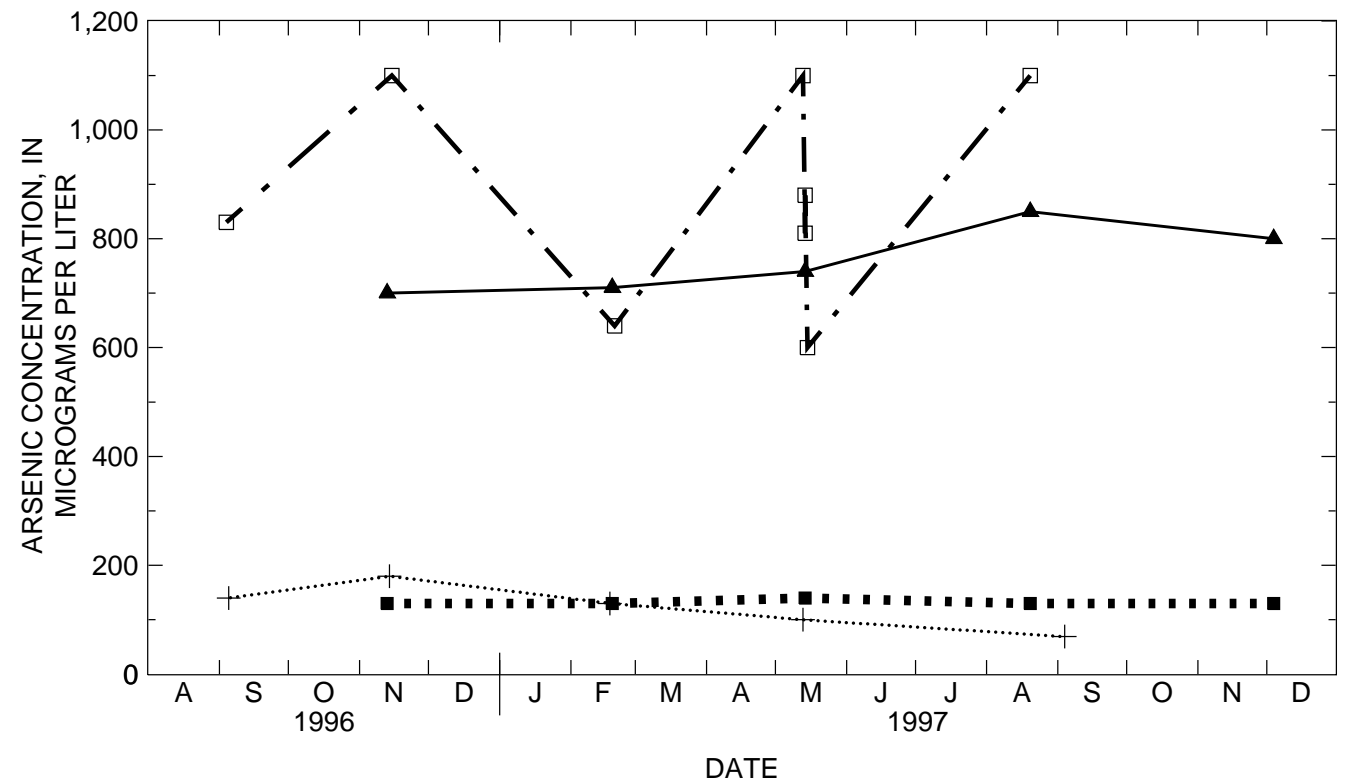

Figure 4. Temporal variations in arsenic concentrations.

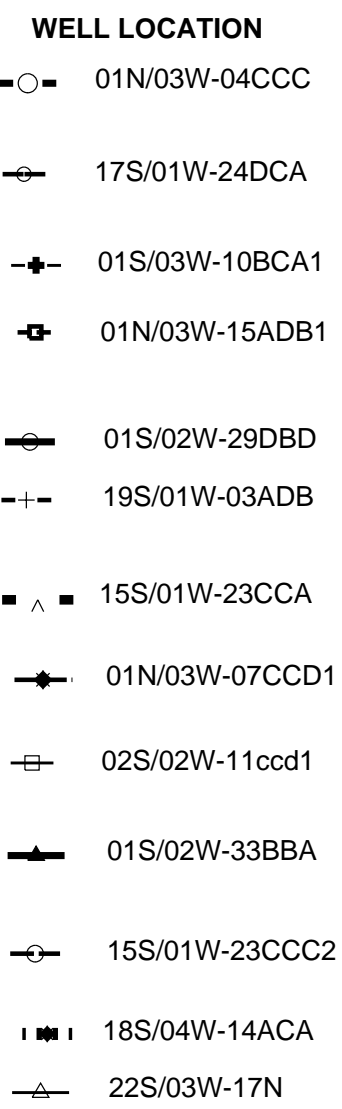

$\rightarrow \quad 18 \mathrm{~S} / 04 \mathrm{~W}-14 \mathrm{BBA}$

$\leftarrow \quad$ 19S/03W-11E2

.. $+\cdots \quad 21 \mathrm{~S} / 03 \mathrm{E}-08 \mathrm{CBD} 2$

' ' 19S/03W-31E1 
37-hour period was as great as the variability observed during the course of a year (table 3, fig. 4). Such variability over the course of 37 hours cannot be ascribed to seasonal factors.

Certainly, a relationship between arsenic concentrations and well use prior to sampling remains only a hypothesis. But regardless of the processes resulting in the observed temporal variability, the data demonstrate that short-term variability in arsenic concentrations can be similar in magnitude to variability observed during the course of quarterly sampling.

The temporal variability of the project data (less than a factor of three) contrasts greatly with temporal variability in arsenic concentrations reported by Nadakavukaren and others (1984) for some wells in Lane County in the southern part of the Willamette Basin. Nadakavukaren and others (1984) reported temporal variability of up to about three orders of magnitude over the course of a year for some of the 14 wells sampled. Such variability is intriguing, because temporal variability of this magnitude in ground-water chemistry at individual sites is unusual.

Nadakavukaren and others (1984) noted that arsenic concentrations often were low (relative to mean concentrations) during the winter (rainy) season. However, they also reported that equally low concentrations were observed during other seasons, including the summer (dry) season, at several sites. Thus, although they observed temporal variability in arsenic concentrations, Nadakavukaren and others (1984) reported that they were unable to relate temporal variability to environmental factors. Unfortunately, sample-collection procedures were not defined in the paper. One aspect of the data not discussed in the original paper, but that may have significant bearing on interpretation of temporal variability, is that most of the wells sampled were irrigation wells. Irrigation wells tend to be unused during the rainy season, and frequently remain idle for long periods during other parts of the year. Recall that it was proposed that temporal variability of project data was related, at least in part, to well use prior to sampling, and recall, also, that project wells either were actively used domestic wells or were sampled after purging three well-bore volumes. It is possible that the extreme variability in arsenic concentrations reported by Nadakavukaren and others (1984) could be related to pre- vious well use (or lack of well use), especially if the wells were not purged prior to sampling. Certainly, the use of irrigation wells for most of the work presented by Nadakavukaren and others (1984), and the absence of documentation of well-purging criteria, make interpretation of their temporal data difficult. Data of Nadakavukaren and others (1984) suggest that caution be applied when using historical data for which both well-use and well-purging information are unavailable.

The absence of seasonal trends in project data suggests that data collected at different times in the Willamette Basin can be combined for use in definition of spatial variability in arsenic concentrations. However, data of Nadakavukaren and others (1984), although difficult to interpret, suggest that historical data for which the history of well use and well purging are unknown may not always be sufficient for site-specific characterization. Thus, although temporal variability is not likely to be a significant problem for a regional evaluation of ground-water arsenic concentrations, the quality of historical data should be evaluated. Most of the historical data compiled for use in this report were from samples collected by USGS personnel. The remainder of the data (from Linn County Department of Health Services, Environmental Health Program) were collected from domestic wells, which presumably were actively used wells. USGS protocols have long required (at least as far back as 1960; Rainwater and Thatcher, 1960) that groundwater samples be collected from purged or actively used wells. Thus, from a standpoint of well use/ well purging, the historical data used in this report are believed to be of adequate quality for a regional assessment of arsenic concentrations in ground water. Resampling of selected wells represented in the historical data supports this assumption, as was shown in the section "Quality of Historical Data."

\section{Spatial Distribution}

Historical and project data were combined and used to evaluate the spatial distribution of arsenic concentrations in ground water of the Willamette Basin. A total of 728 spatially distinct samples thus were available-597 historical and 131 project samples. Of these 728 samples, 721 were from wells, and 7 were from nonthermal springs. These data are available in digital format 
(CD-ROM) in a separate data report (Orzol and others, in press).

Concentrations of arsenic in the 728 samples ranged from $<1$ to $2,000 \mu \mathrm{g} / \mathrm{L}$. A histogram of these data is shown on figure 5 . Concentrations in 58 samples ( 8.0 percent) exceeded the USEPA current MCL (50 $\mu \mathrm{g} / \mathrm{L})$, and 158 (21.7 percent) exceeded the WHO provisional guideline $(10 \mu \mathrm{g} / \mathrm{L})$. The 728 samples were not randomly distributed throughout the basin, so it does not follow that 8 percent of all wells in the basin will exceed the USEPA current MCL. Furthermore, because some of the data (in particular, data of Goldblatt and others, 1963, and data from Linn County Department of Health Services) were collected to address suspected arsenic problems, the cumulative data set contains a bias towards high arsenic concentrations (exceeding the USEPA current MCL). The data do, however, indicate the existence of extensive bodies of high-arsenic ground water in the basin.

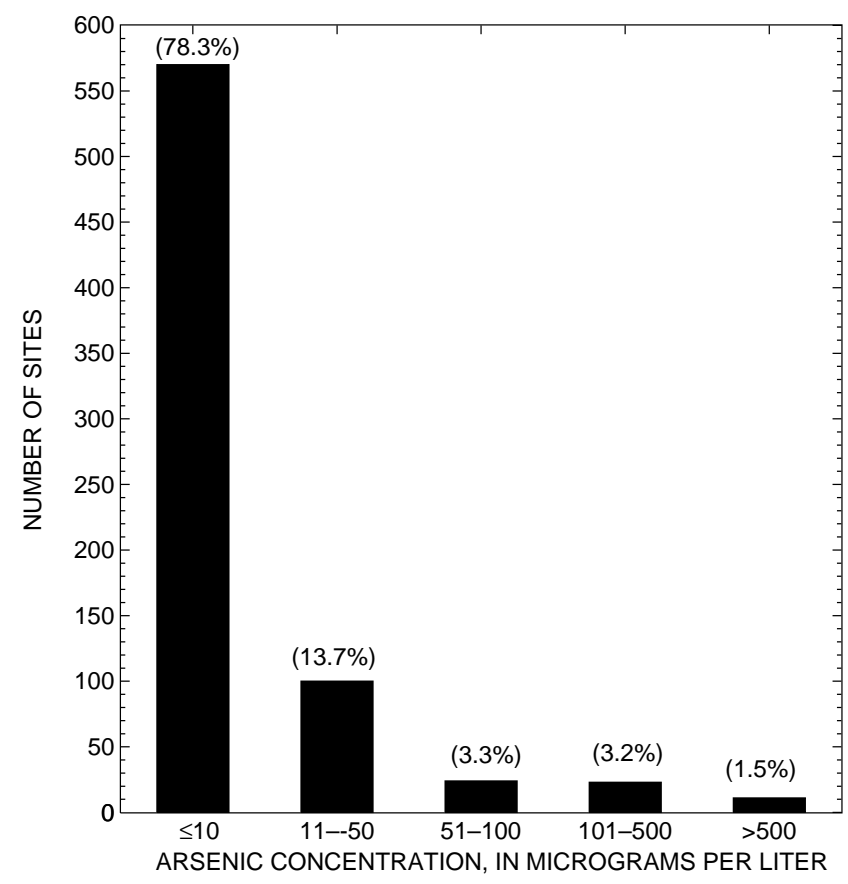

Figure 5. Arsenic concentrations for sites sampled in the Willamette Basin, Oregon. (Number in parentheses is percentage of the total number of sites.)

Depth data were available for 651 of the 728 sites. The relation of arsenic concentration to depth is shown on figure 6. Data from springs were included on this figure; springs were assigned a "well depth" of zero. (For plotting purposes, censored data [concentrations below reporting levels] were arbitrarily plotted at one-half of the reporting

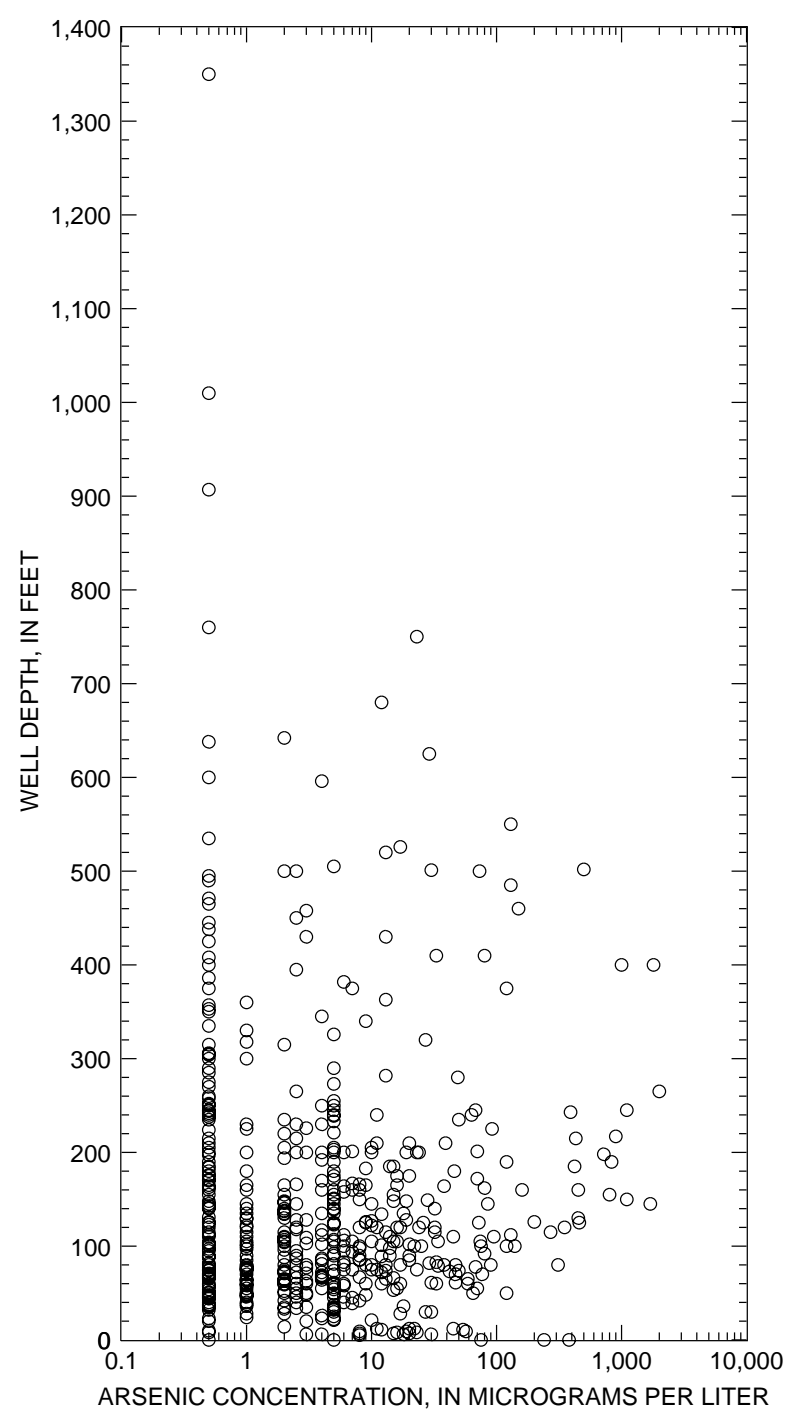

Figure 6. Relation of arsenic concentration to well depth. (Data from six springs also are included; "well depth" is set to zero for springs.)

levels. Censoring occurred at three concentration levels: 1,5 , and $10 \mu \mathrm{g} / \mathrm{L}$.) No obvious relation of arsenic concentration to well depth was observed. On a regional scale, depth does not appear to be a useful parameter for predicting arsenic concentrations. However, depth may be an important parameter on a local scale.

The spatial distribution of arsenic concentrations is shown on plate 1 . Patterns of arsenic occurrence are apparent. Most (53) of the 58 samples with high concentrations of arsenic came from wells and springs in bedrock areas (areas where bedrock is exposed at land surface or is covered by thin layers of alluvium) in south-central and eastern Lane County, and Linn County (pl. 1). The remain- 
ing 5 (of the 58) samples came from wells near the center of the Tualatin Basin in Washington County (northwestern part of the Willamette Basin) (pl. 1). These five wells produce water from alluvial deposits. Not only were most of the 58 occurrences of high arsenic concentrations in Lane and Linn Counties, but the highest concentrations also were found there. Arsenic concentrations ranged up to $2,000 \mu \mathrm{g} / \mathrm{L}$ in Lane and Linn Counties, and six samples contained $\geq 1,000 \mu \mathrm{g} / \mathrm{L}$. In contrast, the maximum concentration of arsenic in the Tualatin Basin, $77 \mu \mathrm{g} / \mathrm{L}$, was substantially smaller than many of the concentrations found in Lane and Linn Counties, although still a concentration of considerable concern.

All five exceedances of the USEPA current MCL in the Tualatin Basin were from filtered samples. Many of the exceedances of the USEPA current MCL in Lane and Linn Counties were from unfiltered samples, but concentrations in filtered samples from that part of the Willamette Basin have been observed to exceed 1,000 $\mu \mathrm{g} / \mathrm{L}$. Because filtered samples generally contain primarily dissolved constituents, the presence of high concentrations of arsenic in filtered samples suggests that geochemical conditions can be favorable for development of high dissolved-arsenic concentrations both in the Tualatin Basin and in bedrock areas of Lane and Linn Counties.

Intermediate arsenic concentrations $(>10$ $\mu \mathrm{g} / \mathrm{L}$ and $\leq 50 \mu \mathrm{g} / \mathrm{L})$ were widespread in the Willamette Basin (pl. 1). As might be expected, many of the occurrences of intermediate arsenic concentrations were located in the same regions where high arsenic concentrations were found. However, intermediate arsenic concentrations were found in many other areas as well, and in a variety of geologic materials.

Occurrence of high concentrations of arsenic in bedrock areas of Lane and Linn Counties appears to be related to the areal extent of two associations of older volcanic rocks: (1) the Fisher and Eugene Formations and correlative rocks (Oligocene and upper Eocene epochs), and (2) undifferentiated tuffaceous sedimentary rocks, tuffs, and basalt (Miocene and Oligocene epochs). (The undifferentiated tuffaceous sedimentary rocks, tuffs, and basalt are approximately equivalent to the Little Butte Volcanic Series of Peck and others [1964].) The surficial extent of these two rock associations is shown on plate 1 . At land surface, the two rock associations cover 24 percent of the Willamette Basin. All detections of high concentrations of arsenic in Lane and Linn Counties occur in or very close to places where these volcanic rocks crop out, or in areas where thin layers of alluvial materials cover the rocks. These rocks include extensive volumes of silicic (rhyolitic) volcanic rocks. Ground water high in naturally occurring arsenic commonly is associated with volcanic rocks silicic to intermediate in composition (Welch and others, 1988). Thus, the apparent relationship between high concentrations of arsenic and geologic unit is not unexpected.

Interpretation of relationships between high concentrations of arsenic in ground water and geologic units could be improved upon at a local scale by use of more detailed (local) geologic maps. For example, although high concentrations of arsenic often occur in water within the Fisher and Eugene Formations and correlative rocks, Goldblatt and others (1963) suggest that the Fisher Formation, and not the Eugene Formation, is the source of most of the arsenic in that area. Similarly, water within basalt flows in the undifferentiated tuffaceous sedimentary rocks, tuffs, and basalt is not a likely candidate for high concentrations of arsenic because basalt typically yields water low in arsenic (Welch and others, 1988). The regional nature of the work presented in this report, with the requisite use of regional-scale rock associations, did not allow for finer-scale interpretation of the occurrence of high concentrations of arsenic relative to geologic characteristics. However, investigators involved in local-scale ground-water assessments should be able to make use of more detailed geologic mapping to help guide sampling.

Large portions of the area covered by the Fisher and Eugene Formations and correlative rocks, and the undifferentiated tuffaceous sedimentary rocks, tuffs, and basalt, are not represented by data collected and compiled for this report.

Although most of the unsampled areas underlain by these rocks are not densely populated, they are not uninhabited, and the potential for impacts to human health are not insignificant. The surface exposure of these rocks alone represents 24 percent of the area of the Willamette Basin, and their full extent is greater. Additional sampling of wells completed in these arsenic-containing rocks would better define 
the spatial distribution of high-arsenic water in areas not sampled during this study. Further, the presence of high arsenic concentrations in other aquifers in the Willamette Basin (pl. 1) suggests that additional sampling might reveal still more problem areas.

\section{GEOCHEMISTRY OF ARSENIC}

An understanding of factors controlling the distribution of arsenic in ground water requires a knowledge of arsenic sources and of processes controlling arsenic mobility. To that end, possible sources of arsenic in Willamette Basin ground water are discussed in this section. Processes that have been shown to control arsenic mobility in other natural systems are discussed next. Then, arsenic speciation data collected as part of this project, along with some historical speciation data, are presented. Finally, geochemical data (including the speciation data) and information from existing interpretive reports are used to construct preliminary hypotheses regarding possible geochemical controls over mobilization of arsenic in the Willamette Basin. An understanding of arsenic sources and geochemistry in the basin could help guide future monitoring efforts both in the basin and elsewhere. However, rigorous geochemical investigation of reasonable hypotheses will be required before an adequate understanding of arsenic geochemistry in the Willamette Basin can be said to exist. Thus, this discussion may serve future research.

\section{Sources of Arsenic}

Arsenic can be introduced into ground water from anthropogenic and natural sources. Anthropogenic sources may be important in some settings. Because industrial activity tends to be localized, it would be difficult to explain regional patterns of arsenic occurrence in the Willamette Basin by introduction from industrial sources. However, arsenical pesticides such as lead arsenate were historically used in large quantities in agricultural areas of the Willamette Basin (Rinehold and Jenkins, 1993). High-arsenic ground water in bedrock areas of Lane and Linn County tends to occur in nonagricultural areas, so it is unlikely that the observed high concentrations of arsenic in ground water in those areas can be attributed to historical use of arsenical pesticides. However, in contrast to land-use patterns in the bedrock areas of Lane and Linn Counties, land use in alluvial portions of the Tualatin Basin includes a variety of agricultural land uses, and high-arsenic ground water in alluvium in the Tualatin Basin does generally coincide with occurrence of agricultural areas. Closer inspection of the data, however, shows that detections of high concentrations of arsenic in Tualatin Basin ground water generally are near rivers and streams (pl. 1). Ground water near these rivers and streams likely represents ground water near the end of ground-water flowpaths. Occurrence of high concentrations of arsenic in downgradient parts of ground-water flowpaths could result from transport of arsenic from upgradient areas where arsenical pesticides historically had been applied, or from mobilization of naturally occurring arsenic during geochemical evolution as ground water moves along flowpaths. Arsenic is nearly immobile in topsoils, and arsenic in arsenical-pesticide-contaminated topsoil leaches on timescales of decades or more (Aten and others, 1980). Thus, occurrence of high concentrations of arsenic primarily in downgradient areas, and not more uniformly distributed in the Tualatin Basin, is more consistent with a natural source than an anthropogenic source. However, no rigorous ground-water flowpath analysis has been done for arsenic transport in the Tualatin Basin, and instances of leaching of arsenic from sites of historical arsenical use into ground water of the Tualatin Basin cannot be ruled out. Nonetheless, regional patterns of arsenic concentrations in ground water of the Willamette Basin as a whole probably reflect primarily natural sources.

Naturally occurring arsenic commonly is found in volcanic glass in volcanic rocks of rhyolitic to intermediate composition; adsorbed to and coprecipitated with metal oxides, especially iron oxides; adsorbed to clay-mineral surfaces; and associated with sulfide minerals and organic carbon (Welch and others, 1988). Sulfide minerals can contain arsenic either as a dominant mineral-forming element or as an impurity; sulfide minerals are found locally in the Western Cascades (U.S. Geological Survey, 1969). Metal oxides and clay minerals are ubiquitous in the Willamette Basin. Organic carbon is widespread in many parts 
of the Willamette Basin, especially in alluvial deposits. Volcanic glass, commonly a major component of volcanic rocks, also is widely found in Willamette Basin aquifers, although much of the original glass in older volcanic rocks has been devitrified (Peck and others, 1964). Thus, arsenic originally associated with such volcanic glass either will have become associated with devitrification alteration products such as clays and metal oxides, or will have been released into solution and subsequently adsorbed or precipitated elsewhere or flushed from the aquifer. However, volcanic glass is still abundant in the Willamette Basin, and thus may constitute a current source of arsenic. At a minimum, the apparent relationship between rock associations containing silicic volcanic rocks and the occurrence of high concentrations of arsenic in ground water in Lane and Linn Counties described earlier in this report suggests that considerable amounts of arsenic might ultimately have come from volcanic glass. Thus, several sources of naturally occurring arsenic dispersed in aquifer materials can reasonably be postulated. However, examination of these various potential arsenic sources for arsenic availability in the Willamette Basin apparently has never been done.

\section{Review of Geochemical Processes Control- ling Arsenic Mobility}

Two categories of processes largely control arsenic mobility in aquifers: (1) adsorption and desorption reactions and (2) solid-phase precipitation and dissolution reactions. Attachment of arsenic to an iron oxide surface is an example of an adsorption reaction. The reverse of this reaction, arsenic becoming detached from such a surface, is an example of desorption. Solid-phase precipitation is the formation of a solid phase from components present in aqueous solution. Precipitation of the mineral calcite, from calcium and carbonate present in ground water, is an example of solid-phase precipitation. Dissolution of volcanic glass within an aquifer is an example of solid-phase dissolution.

Arsenic adsorption and desorption reactions are influenced by changes in $\mathrm{pH}$, occurrence of redox (reduction/oxidation) reactions, presence of competing anions, and solid-phase structural changes at the atomic level. Solid-phase precipita- tion and dissolution reactions are controlled by solution chemistry, including $\mathrm{pH}$, redox state, and chemical composition.

\section{Adsorption and Desorption Processes}

Arsenic is a redox-sensitive element. This means that arsenic may gain or lose electrons in redox reactions. As a result, arsenic may be present in a variety of redox states. Arsenate and arsenite are the two forms of arsenic commonly found in ground water (Masscheleyn and others, 1991). Arsenate generally predominates under oxidizing conditions. Arsenite predominates when conditions become sufficiently reducing. Under the $\mathrm{pH}$ conditions of most ground water, arsenate is present as the negatively charged oxyanions $\mathrm{H}_{2} \mathrm{AsO}_{4}{ }^{-}$or $\mathrm{HAsO}_{4}{ }^{2-}$, whereas arsenite is present as the uncharged species $\mathrm{H}_{3} \mathrm{AsO}_{3}{ }^{0}$ (Hem, 1985). The strength of adsorption and desorption reactions between these different arsenic species and solid-phase surfaces in aquifers varies, in part, because of these differences in charge. Differences in species charge affect the character of electrostatic interactions between species and surfaces.

Arsenate and arsenite adsorb to surfaces of a variety of aquifer materials, including iron oxides, aluminum oxides, and clay minerals. Adsorption and desorption reactions between arsenate and iron-oxide surfaces are particularly important controlling reactions because iron oxides are widespread in the hydrogeologic environment as coatings on other solids, and because arsenate adsorbs strongly to iron-oxide surfaces in acidic and near-neutral-pH water (Dzombak and Morel, 1990; Waychunas and others, 1993). However, desorption of arsenate from iron-oxide surfaces becomes favored as $\mathrm{pH}$ values become alkaline (Fuller and Davis, 1989; Dzombak and Morel, 1990). The $\mathrm{pH}$-dependence of arsenate adsorption to iron-oxide surfaces appears to be related to the change in iron-oxide net surface charge from positive to negative as $\mathrm{pH}$ increases above the zero-point-of-charge ( $\mathrm{pH}$ at which the net surface charge is equal to zero) of about 7.7 for goethite (crystalline iron oxide) (Stumm and Morgan, 1996) or 8.0 for ferrihydrite (amorphous iron oxide) (Dzombak and Morel, 1990). Where $\mathrm{pH}$ values are above about 8 , the negative net surface charge of 
iron oxide can repel negatively charged ions such as arsenate.

Iron-oxide surfaces also adsorb arsenite, and both arsenate and arsenite adsorb to aluminum oxides and clay-mineral surfaces. However, these adsorption reactions appear generally to be weaker than is the case for arsenate adsorption to iron-oxide surfaces under typical environmental $\mathrm{pH}$ conditions (Manning and Goldberg, 1997). Nevertheless, $\mathrm{pH}$-dependent adsorption and desorption reactions other than those between arsenate and iron-oxide surfaces may be important controls over arsenic mobility in some settings. As is the case for adsorption of arsenate to iron-oxide surfaces, adsorption of arsenite to iron-oxide surfaces tends to decrease as $\mathrm{pH}$ increases, at least between the range from $\mathrm{pH} 6$ to $\mathrm{pH} 9$ (Dzombak and Morel, 1990). Unfortunately, arsenate and arsenite adsorption and desorption reactions with other common surfaces are less well characterized, and apparently more complex than is the case for adsorption and desorption reactions with iron-oxide surfaces (Manning and Goldberg, 1997).

As a result of the $\mathrm{pH}$ dependence of arsenic adsorption, changes in ground-water $\mathrm{pH}$ can promote adsorption or desorption of arsenic. Because solid-phase diagenesis (water-rock interaction) typically consumes $\mathrm{H}^{+}$(Stumm and Morgan, 1996), the $\mathrm{pH}$ of ground water tends to increase with residence time, which, in turn, increases along ground-water flowpaths. Because iron-oxide surfaces can hold large amounts of adsorbed arsenate, geochemical evolution of ground water to high (alkaline) $\mathrm{pH}$ can induce desorption of arsenic sufficient to result in exceedances of the USEPA current MCL in some environments (see, for example, Robertson, 1989).

Similarly, redox reactions can control aqueous arsenic concentrations by their effects on arsenic speciation, and hence, arsenic adsorption and desorption. For example, reduction of arsenate to arsenite can promote arsenic mobility because arsenite is generally less strongly adsorbed than is arsenate. Redox reactions involving either aqueous or adsorbed arsenic can affect arsenic mobility (Manning and Goldberg, 1997).

Arsenic adsorption also can be affected by the presence of competing ions. In particular, phosphate and arsenate have similar geochemical behavior, and as such, both compete for sorption sites (Hingston and others, 1971; Livesey and Huang, 1981; Manning and Goldberg, 1996). Oxyanions in addition to phosphate also may compete for sorption sites. For example, Robertson (1989) suggested that correlation of arsenate with oxyanions of molybdenum, selenium, and vanadium in ground water of the Southwestern United States may be evidence for competitive adsorption among those oxyanions.

Finally, structural changes in solid phases at the atomic level also affect arsenic adsorption and desorption. For example, conversion of ferrihydrite to goethite or to other crystalline iron-oxide phases may occur gradually over time (Dzombak and Morel, 1990). Fuller and others (1993) demonstrated that as ferrihydrite crystallizes into goethite, the density of arsenic adsorption sites decreases. This decrease in density of adsorption sites can result in desorption of adsorbed arsenic. Structural changes in other solid phases may possibly affect arsenic mobility, too. The role of such solid-phase structural changes on ground-water arsenic concentrations has, however, received little attention to date.

\section{Precipitation and Dissolution Processes}

The various solid phases (minerals, amorphous oxides, volcanic glass, organic carbon) of which aquifers are composed exist in a variety of thermodynamic states. At any given time, some aquifer solid phases will be undergoing dissolution, whereas others will be precipitating from solution. Arsenic contained within solid phases, either as a primary structural component of or an impurity in any of a variety of solid phases, is released to ground water when those solid phases dissolve. Similarly, arsenic is removed from ground water when solid phases containing arsenic precipitate from aqueous solution. As an example, because arsenic often coprecipitates with iron oxide (Waychunas and others, 1993), iron oxide may act as an arsenic source (case of dissolution) or a sink (case of precipitation) for ground water. Furthermore, solid-phase dissolution will contribute not only arsenic contained within that phase, but also any arsenic adsorbed to the solid-phase surface. The process of release of adsorbed arsenic as a result of solid-phase dissolution is distinct from the process of desorption from stable solid phases. 
The interplay of redox reactions and solid-phase precipitation and dissolution may be particularly important with regard to aqueous arsenic and solid-phase iron oxides and sulfide minerals. High concentrations of arsenic often are associated with iron oxides and sulfide minerals (Thornton, 1996). Iron oxides frequently dissolve under reducing conditions, but often precipitate under oxidizing conditions. Sulfide minerals generally are unstable under oxidizing conditions, but may precipitate under reducing conditions. Thus, as a result of the redox-sensitive nature of iron oxides and sulfide minerals, transfer of large amounts of arsenic between these solid phases and neighboring water may result from redox-facilitated precipitation and dissolution reactions.

\section{Arsenic Speciation in the Willamette Basin}

Three samples from alluvial wells in the Tualatin Basin and two from bedrock wells in Lane County were analyzed for four common species of arsenic. Concentrations of the two organic species of arsenic analyzed (monosodium methylarsonate, or $\mathrm{CH}_{3} \mathrm{AsO}_{3} \mathrm{HNa}$, and sodium dimethylarsinate, or $\left.\left(\mathrm{CH}_{3}\right)_{2} \mathrm{AsO}_{2} \mathrm{Na}\right)$ were below MDLs, so only the data for the two inorganic species are tabulated. These speciation data are given in table 4 .

Two additional analyses for arsenic species in ground water from the Willamette Basin were available in the literature. Welch and others (1988) reported arsenite and arsenate concentrations for water from two wells in Lane County. Arsenite represented 7 percent and 62 percent of the total arsenic in these samples (total arsenic concentrations being 25 and $45 \mu \mathrm{g} / \mathrm{L}$, respectively).
The most striking feature of the data from the two studies is the predominance of arsenite. The predominance of arsenite has both geochemical and toxicological implications. From a geochemical standpoint, the speciation data are of interest because mobility of arsenite differs from that of arsenate (see section "Review of Geochemical Processes Controlling Arsenic Mobility"). From a public-health perspective, the speciation data are interesting because arsenite is more toxic than arsenate in at least some of its effects. In human acute toxicity studies, arsenite has been shown to be more potent than arsenate (U.S. Environmental Protection Agency, 1988). With regard to human chromosome breakage, arsenite is about an order of magnitude more potent than arsenate (U.S. Environmental Protection Agency, 1988). Morrison and others (1989) report that arsenite is 50 times as toxic as arsenate, but do not report the organisms studied. Also, arsenite is more difficult to remove from drinking-water supplies than is arsenate (Gupta and Chen, 1978; Schneiter and Middlebrooks, 1983). However, it would be premature to make generalizations regarding arsenic toxicity in the Willamette Basin based upon such limited speciation data (seven samples). Complicating the matter, in the benchmarks against which drinking water arsenic concentration data commonly are compared-the USEPA current MCL and the WHO provisional guideline-no differen- tiation is made between arsenite and arsenate. But if the apparent predominance of arsenite in Willamette Basin ground water is confirmed by additional speciation work, public health officials and water managers may need to evaluate the scope of the arsenic problem with regard not only to arsenic concentrations, but also to arsenic speciation.

Table 4. Speciation of arsenic

[Total arsenic concentration is from a separate analysis of a separate sample, and differs from the total of arsenite-plus-arsenate because of sampling and (or) analytical variability. Recovery, total of arsenite-plus-arsenate divided by total arsenic; $\mu \mathrm{g} / \mathrm{L}$, micrograms per liter]

\begin{tabular}{|c|c|c|c|c|c|c|c|c|}
\hline Well location & Date & $\begin{array}{l}\text { Arsenite } \\
\text { (percent of } \\
\text { total of } \\
\text { arsenite-plus- } \\
\text { arsenate) }\end{array}$ & $\begin{array}{l}\text { Arsenate } \\
\text { (percent of } \\
\text { total of } \\
\text { arsenite-plus- } \\
\text { arsenate) }\end{array}$ & $\begin{array}{c}\text { Arsenite } \\
(\mu \mathbf{g} / L)\end{array}$ & $\begin{array}{c}\text { Arsenate } \\
(\mu \mathbf{g} / L)\end{array}$ & $\begin{array}{l}\text { Total of } \\
\text { arsenite-plus- } \\
\text { arsenate } \\
(\mu \mathrm{g} / \mathrm{L})\end{array}$ & $\begin{array}{c}\text { Total arsenic } \\
\text { concentration } \\
(\mu \mathrm{g} / \mathrm{L})\end{array}$ & $\begin{array}{l}\text { Recovery } \\
\text { (percent) }\end{array}$ \\
\hline$\overline{01 \mathrm{~N} / 03 \mathrm{~W}-04 \mathrm{CCC}}$ & $08 / 19 / 97$ & 76 & 24 & 61.1 & 18.9 & 80.0 & 97 & 82 \\
\hline 01S/03W-10BCA1 & 08/19/97 & 96 & 4 & 58.8 & 2.3 & 61.1 & 56 & 110 \\
\hline 02S/02W-11CCD1 & 08/19/97 & 94 & 6 & 15.3 & .9 & 16.2 & 19 & 85 \\
\hline 18S/04W-14BBA & 08/20/97 & $>99$ & $<1$ & 1,200 & 6.1 & 1,210 & 1,100 & 110 \\
\hline 19S/03W-31E1 & 08/20/97 & 68 & 32 & 61.5 & 29.4 & 90.9 & 130 & 70 \\
\hline
\end{tabular}




\section{Geochemistry of Arsenic in the Willamette Basin}

Few routine chemical analyses (of major ions and field parameters) are available for high-arsenic ground water from bedrock areas of Lane and Linn Counties. Goldblatt and others (1963) noted that high-arsenic ground water tended to have high $\mathrm{pH}$ (>8.0) and high orthophosphate concentrations, although only two routine chemical analyses for high-arsenic ground water were published. Reliable measures of redox conditions were not collected. However, the observation was made during site visits that water from many of the wells in bedrock areas of Lane and Linn Counties that yielded high-arsenic ground water during project sampling also had sulfide odors. The presence of sulfide in water indicates chemically reducing conditions. The observation of sulfide, along with the detection of arsenite (the more reduced of the two major arsenic species) in some ground-water samples, indicates the presence of reducing conditions in some ground water in these areas.

Together, these data suggest that for ground water in bedrock areas of Lane and Linn Counties, one or more of the following controlling factors likely are important in adsorption and desorption reactions that in turn often control arsenic mobility: (1) high $\mathrm{pH}$, (2) presence of competing anions, and (3) occurrence of reducing conditions. The sparse available data do not allow even for speculation about adsorption and desorption reactions related to solid-phase structural changes at the atomic level in ground water of bedrock areas of Lane and Linn Counties. Similarly, evidence is lacking to even begin to develop hypotheses about solid-phase precipitation and dissolution reactions.

Previous investigations of the quality of Tualatin Basin ground water provide some preliminary insight into arsenic geochemistry there. Rounds and others (1994) reported that high phosphorus concentrations (up to $2.9 \mathrm{mg} / \mathrm{L}$ [milligrams per liter]) are common in Tualatin Basin ground water. In an analysis of 47 filtered ground-water samples from the Tualatin Basin, Hinkle (1997) reported that the median arsenic concentration in low-dis- solved-oxygen samples (dissolved oxygen concentrations $<1.0 \mathrm{mg} / \mathrm{L}$ ) was greater than the median arsenic concentration in well-oxygenated samples. The difference was statistically significant. Of the 47 samples, the 4 that exceeded the USEPA current MCL not only had low dissolved-oxygen concentrations, but also had high concentrations of orthophosphate (0.36 to 2.0

$\mathrm{mg} / \mathrm{L})$ and iron (160 to $1,900 \mu \mathrm{g} / \mathrm{L})$. However, $\mathrm{pH}$ was not unusually high; $\mathrm{pH}$ of three of the four high-arsenic samples ranged from 7.5 to 7.6 , and was 8.1 for the fourth sample.

These data suggest that for alluvial ground water in the Tualatin Basin, presence of competing anions and occurrence of reducing conditions may be important controlling factors in arsenic adsorption and desorption reactions. These two factors might be more important than $\mathrm{pH}$ controls over arsenic adsorption and desorption. Reducing conditions and high concentrations of dissolved iron also suggest that dissolution of iron oxides, with subsequent release of adsorbed or coprecipitated arsenic, may play a role in arsenic mobility in the Tualatin Basin.

Hypotheses about factors affecting arsenic adsorption and desorption reactions should account for arsenic speciation. Limited geochemical data suggest that desorption of arsenic from solid phases may be an important process in ground water both in bedrock areas of Lane and Linn Counties and in alluvium in the Tualatin Basin. Desorption of arsenate from iron oxides commonly results from high $\mathrm{pH}$ or the presence of competing ions. Such processes, of course, require the presence of arsenate on solid-phase surfaces. Because redox reactions often are slow and frequently far from equilibrium, it would not be unexpected to find arsenate adsorbed to solid-phase surfaces in chemically reducing environments. It might appear, though, that the predominance of arsenite relative to arsenate in aqueous speciation samples would be inconsistent with a hypothesis of desorption of arsenate from iron-oxide surfaces. However, it may be that arsenate is desorbed from aquifer surfaces and subsequently reduced to arsenite. 


\section{REFERENCES CITED}

Aten, C.F., Bourke, J.B., Martini, J.H., and Walton, J.C., 1980, Arsenic and lead in an orchard environment: Bulletin of Environmental Contamination and Toxicology, v. 24, p. 108115.

Bagla, Pallava, and Kaiser, Jocelyn, 1996, India's spreading health crisis draws global arsenic experts: Science, v. 274, p. 174-175.

Broad, T.M., and Collins, C.A., 1996, Estimated water use and general hydrologic conditions for Oregon, 1985 and 1990: U.S. Geological Survey Water-Resources Investigations Report 964080, $166 \mathrm{p}$.

Cantor, K.P., 1996, Arsenic in drinking water-How much is too much?: Epidemiology, v. 7, p. 113115.

Dzombak, D.A., and Morel, F.M.M., 1990, Surface complexation modeling-Hydrous ferric oxide: New York, John Wiley \& Sons, 393 p.

Fishman, M.J., and Friedman, L.C., eds., 1989, Methods for determination of inorganic substances in water and fluvial sediments: U.S. Geological Survey Techniques of WaterResources Investigations, book 5, chap. A1, $545 \mathrm{p}$.

Frank, F.J., 1973, Ground water in the Eugene-Springfield area, southern Willamette Valley, Oregon: U.S. Geological Survey Water-Supply Paper 2018, 65 p. 1974, Ground water in the Corvallis-Albany area, central Willamette Valley, Oregon: U.S. Geological Survey Water-Supply Paper 2032, $48 \mathrm{p}$.

1976, Ground water in the Harrisburg-Halsey area, southern Willamette Valley, Oregon: U.S. Geological Survey Water-Supply Paper 2040, $45 \mathrm{p}$.

Frank, F.J., and Collins, C.A., 1978, Ground water in the Newberg area, northern Willamette Valley, Oregon: Oregon Water Resources Department Ground-Water Report Number 27, 77 p.

Fuller, C.C., and Davis, J.A., 1989, Influence of coupling of sorption and photosynthetic processes on trace element cycles in natural waters: Nature, v. 340, p. 52-54.

Fuller, C.C., Davis, J.A., and Waychunas, G.A., 1993, Surface chemistry of ferrihydrite, Part 2, Kinetics of arsenate adsorption and coprecipitation: Geochimica et Cosmochimica Acta, v. 57, p. 2271-2282.

Gannett, M.W., and Caldwell, R.R., in press, Geologic framework of the Willamette Lowland Aquifer System, Oregon and Washington: U.S.

Geological Survey Professional Paper 1424-A.

Goldblatt, E.L., Van Denburgh, A.S., and Marsland, R.A., 1963, The unusual and widespread occurrence of arsenic in well waters of Lane County, Oregon: Eugene, Oregon, Lane County Department of Public Health, 24 p.

Gonthier, J.B., 1983, Ground-water resources of the Dallas-Monmouth area, Polk, Benton, and Marion Counties, Oregon: Oregon Water Resources Department Ground-Water Report Number 28, $50 \mathrm{p}$.

Gupta, S.K., and Chen, K.Y., 1978, Arsenic removal by adsorption: Journal Water Pollution Control Fed., v. 50, p. 493-506.

Helm, D.C., and Leonard, A.R., 1977, Ground-water resources of the lower Santiam River Basin, middle Willamette Valley, Oregon: Oregon Water Resources Department Ground-Water Report Number 25, $75 \mathrm{p}$.

Hem, J.D., 1985, Study and interpretation of the chemical characteristics of natural water (3rd ed.): U.S. Geological Survey Water-Supply Paper 2254, $263 \mathrm{p}$.

Hingston, F.J., Posner, A.M., and Quirk, J.P., 1971, Competitive adsorption of negatively charged ligands on oxide surfaces: Discuss. Faraday Soc., v. 52, p. 334-342.

Hinkle, S.R., 1997, Quality of shallow ground water in alluvial aquifers of the Willamette Basin, Oregon, 1993-95: U.S. Geological Survey Water-

Resources Investigations Report 97-4082-B, $48 \mathrm{p}$.

Leonard, A.R., and Collins, C.A., 1983, Ground water in the northern part of Clackamas County, Oregon: Oregon Water Resources Department Ground-Water Report Number 29, 85 p.

Livesey, N.T., and Huang, P.M., 1981, Adsorption of arsenate by soils and its relation to selected chemical properties and anions: Soil Science, v. 131, p. 88-94.

Long, H.K., and Farrar, J.W., 1991, Results of the U.S. Geological Survey's analytical evaluation program for standard reference samples distributed in November 1990- T-113 (trace constituents), M-116 (major constituents), N-28 
(nutrients), N-29 (nutrients), P-16 (precipitationsnowmelt), Hg-9 (mercury), and Hg-10 (mercury): Denver, Colorado, 109 p. 1993, Report on the U.S. Geological Survey's evaluation program for standard reference samples distributed in October 1992: T-121 (trace constituents), M-124 (major constituents), $\mathrm{N}-36$ (nutrients), N-37 (nutrients), P-19 (low ionic strength) and $\mathrm{Hg}-15$ (mercury): U.S. Geological Survey Open-File Report 93-32, $114 \mathrm{p}$.

1995, Report on the U.S. Geological Survey's evaluation program for standard reference samples distributed in October 1994: T-131 (trace constituents), T-133 (trace constituents), M-132 (major constituents), N-43 (nutrients), $\mathrm{N}-44$ (nutrients), P-23 (low ionic strength) and Hg-19 (mercury): U.S. Geological Survey Open-File Report 95-117, 139 p.

Maddy, D.V., Lopp, L.E., Jackson, D.L., Coupe, R.H., and Schertz, T.L., 1990, National Water Information System user's manual, vol. 2, chap. 2, water-quality system: U.S. Geological Survey Open-File Report 89-617, [variously paged].

Manning, B.A., and Goldberg, Sabine, 1996, Modeling arsenate competitive adsorption on kaolinite, montmorillonite and illite: Clays and Clay Minerals, v. 44, p. 609-623.

Manning, B.A., and Goldberg, Sabine, 1997, Adsorption and stability of arsenic (III) at the clay mineral-water interface: Environmental Science and Technology, v. 31, p. 2005-2011.

Masscheleyn, P.H., Delaune, R.D., and Patrick, W.H., Jr., 1991, Effect of redox potential and $\mathrm{pH}$ on arsenic speciation and solubility in a contaminated soil: Environmental Science and Technology, v. 25, p. 1414-1419.

Morrison, G.M.P., Batley, G.E., and Florence, T.M., 1989, Metal speciation and toxicity: Chemistry in Britain, v. 25, p. 791-796

Nadakavukaren, J.J., Ingermann, R.L., Jeddeloh, George, and Falkowski, S.J., 1984, Seasonal variation of arsenic concentration in well water in Lane County, Oregon: Bulletin of Environmental Contamination and Toxicology, v. 33, p. 264-269.

Orzol, L.L., Wozniak, K.C., Meissner, T.R., Lee, D.B., in press, Ground-water and water-chemistry data for the Willamette Basin, Oregon: U.S. Geological Survey Water Resources
Investigations Report 99-4036, 140 p.

Peck, D.L., Griggs, A.B., Schlicker,H.G., Wells, F.G., and Dole, H.M., 1964, Geology of the central and northern parts of the Western Cascade Range in Oregon: U.S. Geological Survey Professional Paper 449, 56 p.

Rainwater, F.H., and Thatcher, L.L., 1960, Methods for collection and analysis of water samples: U.S. Geological Survey Water-Supply Paper 1454, $301 \mathrm{p}$.

Rinehold, J.W., and Jenkins, J.J., 1993, Oregon pesticide use estimates for tree fruits, 1991: Corvallis, Oregon, Oregon State University Extension Service Extension Miscellaneous $8553,38 \mathrm{p}$.

Robertson, F.N., 1989, Arsenic in ground-water under oxidizing conditions, south-west United States: Environmental Geochemistry and Health, v. 11, p. $171-186$

Rounds, S.A., Lynch, D.D., and Caldwell, J.M., 1994, Transport of phosphorus from ground water to the Tualatin River, Oregon [abs.]: Eos, Transactions, American Geophysical Union, v. 75, no. 44, Fall Meeting Supplement, p. 262.

Schneiter, R.W., and Middlebrooks, E.J., 1983, Arsenic and fluoride removal from groundwater by reverse osmosis: Environment International, v. 9, p. 289-292.

Stumm, Werner, and Morgan, J.J., 1996, Aquatic chemistry (3rd ed.): New York, John Wiley and Sons, $1022 \mathrm{p}$.

Thornton, Iain, 1996, Sources and pathways of arsenic in the geochemical environment: health implications, in Appleton, J.D., Fuge, Ron, and McCall, G.J.H., eds., Environmental Geochemistry and Health with Special Reference to Developing Countries, Geological Society Special Publication No. 113: London, Geological Society, p. 153-161.

U.S. Environmental Protection Agency, 1988, Special report on ingested inorganic arsenic-Skin cancer; nutritional essentiality: EPA/625/3-87/ 013F, $124 \mathrm{p}$.

1994, Methods for the determination of metals in environmental samples, supplement I: EPA/ 600/R-94/111, [variously paged]. 
1996, Drinking water regulations and health advisories: EPA-822/B-96/002, 11 p.

U.S. Geological Survey, 1969, Mineral and Water Resources of Oregon, Report prepared by the U.S. Geological Survey at the request of Senator Mark O. Hatfield of Oregon of the Committee on Interior and Insular Affairs, U.S. Senate: Washington, D.C., U.S. Government Printing Office, $462 \mathrm{p}$.

1990, Report of the U.S. Geological Survey's analytical evaluation program-Standard reference water samples T-109 (trace constituents), M-112 (major constituents), $\mathrm{N}-24$ (nutrients), $\mathrm{N}-25$ (nutrients), $\mathrm{P}-14$ (precipitation-snowmelt), and $\mathrm{Hg}-6$ (Mercury): Denver, Colorado, $101 \mathrm{p}$.
Walker, G.W., and MacLeod, N.S., 1991, Geologic map of Oregon: U.S. Geological Survey, scale 1:500,000.

Waychunas, G.A., Rea,B.A., Fuller, C.C., and Davis, J.A., 1993, Surface chemistry of ferrihydritePart 1-EXAFS studies of the geometry of coprecipitated and adsorbed arsenate: Geochimica et Cosmochimica Acta, v. 57, p. 2251-2269.

Welch, A.H., Lico, M.S., and Hughes, J.L., 1988, Arsenic in ground water of the Western United States: Ground Water, v. 26, p. 333-347.

World Health Organization, 1996, Guidelines for drinking-water quality-Volume 2, Health criteria and other supporting information (2nd ed.): Geneva, World Health Organization, 973 p. 
APPENDIX 


\section{APPENDIX}

Table 1. Wells discussed in report text, tables, and figures, listed by well location name from original source, and cross-referenced by recalculated well location and by U.S. Geological Survey site identification number and Oregon Water Resources Department well log identification number

[“--", identical to "Well location (original source)"; N/A, none or not determined].

\begin{tabular}{|c|c|c|c|}
\hline $\begin{array}{l}\text { Well location } \\
\text { (original source) }\end{array}$ & $\begin{array}{l}\text { Well location } \\
\text { (recalculated) }\end{array}$ & $\begin{array}{l}\text { U.S. Geological Survey site } \\
\text { identification number }\end{array}$ & $\begin{array}{c}\text { Oregon Water Resources } \\
\text { Department well log identification } \\
\text { number }\end{array}$ \\
\hline 01N/03W-04CCC & -- & 453540123041101 & WASH 5967 \\
\hline 01N/03W-07CCD1 & -- & 453445123063201 & WASH 6037 \\
\hline 01N/03W-15ADB 1 & -- & 453422123020201 & N/A \\
\hline 01S/02W-29DBD & -- & 452707122572201 & WASH 10406 \\
\hline 01S/02W-33BBA & -- & 452651122565001 & WASH 10475 \\
\hline 01S/03W-10BCA1 & -- & 453002123025301 & WASH 143 \\
\hline 02S/02W-11CCD1 & -- & 452416122541601 & WASH 12572 \\
\hline $12 \mathrm{~S} / 01 \mathrm{~W}-29 \mathrm{~N} 1$ & $12 \mathrm{~S} / 01 \mathrm{~W}-29 \mathrm{CCA}$ & 442934122502801 & LINN 9588 \\
\hline 13S/01E-33 & 13S/01E-33DB1 & 442332122412701 & LINN 12832 \\
\hline $13 \mathrm{~S} / 01 \mathrm{E}-33 \mathrm{AC}$ & -- & 442348122412301 & LINN 12776 \\
\hline $13 \mathrm{~S} / 01 \mathrm{E}-35$ & 13S/01E-35BD1 & 442347122391001 & LINN 12914 \\
\hline 14S/01E-05 & 13S/01E-32CD1 & 442323122424801 & LINN 10997 \\
\hline $15 \mathrm{~S} / 01 \mathrm{~W}-23 \mathrm{CCA}$ & -- & 441447122464501 & LANE 50736 \\
\hline 15S/01W-23CCC2 & -- & 441446122465701 & LANE 5873 \\
\hline 17S/01W-24DCA & -- & 440420122445701 & LANE 2085 \\
\hline 18S/04W-10D & 18S/04W-10BB1 & 440125123095901 & N/A \\
\hline 18S/04W-14ACA & -- & 440029123080301 & LANE 17048 \\
\hline 18S/04W-14ACB & -- & 440024123080901 & LANE 17052 \\
\hline 18S/04W-14BBA & -- & 440036123083201 & LANE 16780 \\
\hline $18 \mathrm{~S} / 04 \mathrm{~W}-22 \mathrm{~B}$ & 18S/04W-22BA1 & 435942123092501 & N/A \\
\hline 19S/01W-03ADB & -- & 435656122471801 & LANE 19429 \\
\hline 19S/03W-11E2 & 19S/03W-11BC3 & 435606123012501 & N/A \\
\hline 19S/03W-31E1 & 19S/03W-31BB1 & 435237123061801 & N/A \\
\hline 21S/03E-08CBD2 & -- & 434528122290901 & LANE 23527 \\
\hline $22 \mathrm{~S} / 03 \mathrm{~W}-17 \mathrm{~N}$ & $22 \mathrm{~S} / 03 \mathrm{~W}-17 \mathrm{CC} 1$ & 433859123045601 & N/A \\
\hline
\end{tabular}




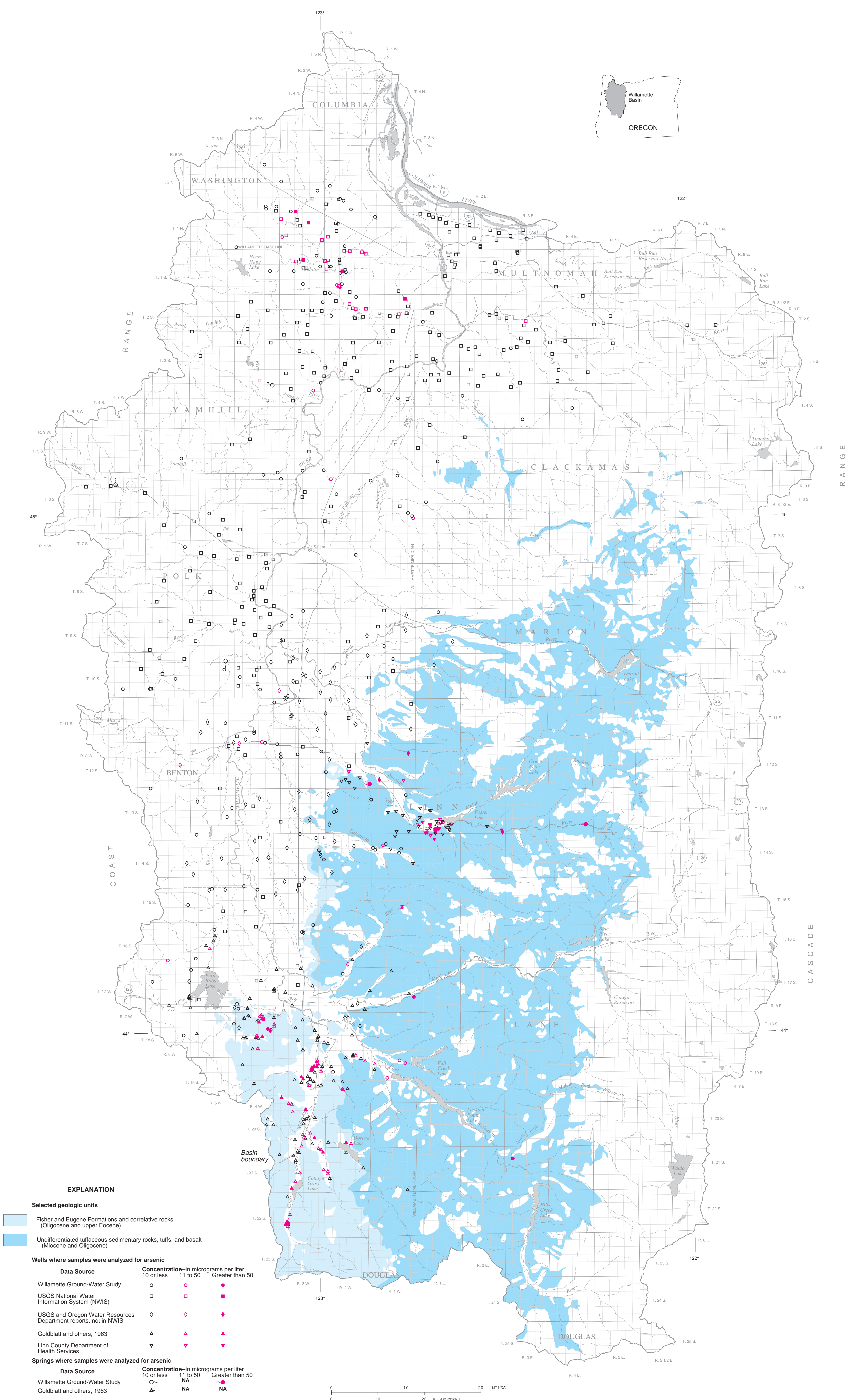

